\title{
Early Cretaceous dinoflagellate cysts from the southern border of the Neuquén Basin, Estancia Santa Elena locality, Argentina"
}

\author{
Wolfgang VOLKHEIMER \\ Instituto Argentino de Nivología, Glaciología y Ciencias Ambientales (IANIGLA), CCT - CONICET - Mendoza. \\ Avenida Adrián Ruiz Leal s/n., Parque General San Martín, (5500) Mendoza, Argentina. \\ E-mail: volkheim@mendoza-conicet.gov.ar

\begin{abstract}
An assemblage of dinoflagellate cysts is reported from the Lower Member (Pilmatué Member) of the Agrio Formation (late Valanginian-Hauterivian) of the southern Neuquén Basin, Argentina. Thirty species are recognized and the new species Oligosphaeridium quattrocchioae and Muderongia sarjeantii described. The studied assemblage is compared with other Early Cretaceous assemblages from central western Argentina, Patagonia, the South Atlantic Malvinas Plateau, the Antarctic Peninsula and Australia. The marine dinoflagellate cyst assemblage of the Agrio Formation at the Estancia Santa Elena locality has cosmopolitan character, with a predominance of European and Tethyan species.
\end{abstract}

Key words: palynology, dinoflagellate cysts, taxonomy, Cretaceous, Argentina, Neuquén Basin, Agrio Formation.

Resumen: Quistes de dinoflagelados del Cretácico Temprano del borde austral de la Cuenca Neuquina, de la localidad de Estancia Santa Elena, Argentina. Se describe una asociación de quistes de dinoflagelados del Miembro Inferior (Miembro Pilmatué) de la Formación Agrio (Valanginiano tardío-Hauteriviano) de la parte austral de la Cuenca Neuquina, Argentina. Se reconocen 30 morfotipos y se describen las nuevas especies Oligosphaeridium quattrocchioae y Muderongia sarjeantii. La asociación estudiada se compara con otras asociaciones de quistes de dinoflagelados del centro oeste de Argentina, de Patagonia, el Plateau de las Malvinas en el Atlántico Sur, la Península Antártica y Australia. La asociación de quistes de dinoflagelados tiene carácter cosmopolita, con predominio de formas europeas y tethianas.

Palabras clave: Palinología, quistes de dinoflagelados, taxonomía, Cretácico, Argentina, Cuenca Neuquina, Formación Agrio.

\section{INTRODUCTION}

The main objective of this paper is to present and illustrate new data on marine dinoflagellate cyst assemblages of the Lower Member (Pilmatué Member) of the Agrio Formation. An assemblage of continental palynomorphs, described earlier (Volkheimer \& Prámparo, 1984) from the Agrio Formation of the same locality, bearing the $C y$ clusphaera psilata-Classopollis assemblage and Balmeiopsis limbatus, is characteristic for the phytogeographic Southern Gondwana province (Brenner, 1976) and specially for the Cyclusphaera psilata subprovince of southwestern Gondwana (Volkheimer, 1980).

The material studied is from outcrop samples of the Lower Member (Pilmatué Member) of the Agrio Formation, of which the lowermost $144 \mathrm{~m}$

\footnotetext{
* In Memory of Dr. William Antony Swithin Sarjeant
}

crop out at Estancia Santa Elena (Figs. 1 and 2). Well-preserved assemblages of dinoflagellate cysts are present only in the lowermost $25 \mathrm{~m}$ of the section. Between 25 and $87 \mathrm{~m}$ the preservation is poor, and in the uppermost part of the section (from 87 to $144 \mathrm{~m}$ ) it is very poor. The general stratigraphic setting is presented on Table 1 and the stratigraphic levels bearing the dinoflagellate cyst assemblages are displayed in Table 2.

The Agrio Formation was proposed by Weaver (1931), for the strata deposited on the top of the sandstones of the Early Cretaceous (Valanginian) Mulichinco Formation and beneath the Rayosa Formation. He divided the Agrio Formation into a lower part composed by "Marine Black Shales", a middle part of sandstones resistant to erosion (the "Avilé Sandstone") and an upper part composed of "Marine Black shales", "Shallow Water Bivalve Beds" and "Gypsum" (Correlation Chart in Weaver, 1931). The latter two units became known as "Huitriniano" (Groeber, 1946) and finally as the "Huitrín Formation" (Digregorio, 1972). 

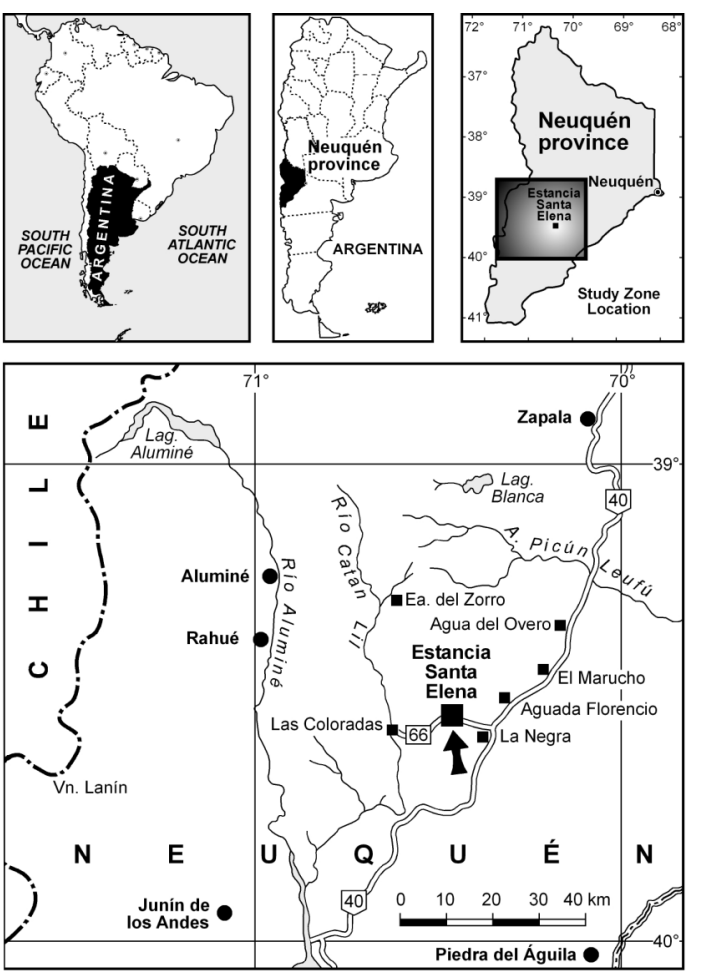

Fig. 1. Location map. / Mapa de ubicación.

The area sampled is located within the geologic map "Hoja 37c-Catán Lil, Neuquén province" of the Servicio Geológico Nacional (Leanza \& Leanza, 1979). The main unconformities which produced major order break-ups during the evolution of the Mesozoic sedimentary infill of the Neuquén Basin, were studied by Leanza (2009). In this southernmost area of the basin he considered the Intravalanginian Movements, producing the Huncálican (Catanlilican) Unconformity.

A synthesis of the biostratigraphy of the Agrio Formation, based on ammonites, palynomorphs and calcareous nannofossils, was given by Aguirre-Urreta et al. (1999). The ammonites from the Agrio Formation indicate a late Valanginian to early Barremian age (Table 1 ). The position of the Agrio Formation in the context of facies evolution of the Mesozoic Neuquén Basin was given in Leanza et al. (2000) and Lazo (2006) studied the taphonomy of the Pilmatué Member macrofauna (= Lower Member) of the Agrio Formation. The biofacies and sea level changes of the Pilmatué Member were analysed by Lazo (2007). His studies on the biofacies are based on corals, serpulids, bivalve mollusks and gastropods, which are the principal components of the benthonic macrofauna of this member.
Lazo et al. (2009) presented an integrated biostratigraphy of the Agrio Formation at its type locality (Bajado del Agrio). They correlated biostratigraphically the local section with the European standard zonations.

Concheyro et al. (2009) studied the micropaleontology of the Agrio Formation in different areas of the Neuquén Basin. They found that in central and southern positions of the Neuquén Basin the age of calcareous nannofossil assemblages is Late Valanginian - Late Hauterivian and that the benthic microfauna indicates frequent eustatic variations (from shelves to shallow marine) with conditions of normal salinity.

Ottone (2009) gave a thorough review of the paleoenvironmental and paleoclimatic significance of the Cretaceous flora of the Neuquén Basin, principally based on the palynologic record, considering 191 papers related to the subject.

The sequence stratigraphy of the Agrio Formation was first interpreted by Legarreta \& Gulisano (1989) and followed by the facies and sequence analysis in the central and southern Neuquén Basin of Brinkmann (1994). Volkheimer \& Prámparo (1984) studied the terrestrial palynoflora associated with the dinoflagellate cysts of Estancia Santa Elena and Volkheimer \& Sarjeant (1993) described Systematophora rosenfeldii from this locality.

Dinoflagellate cysts from other localities were studied by Quattrocchio \& Volkheimer (1990), providing a range chart with 11 species of dinoflagellate cysts from the Agrio Formation) and Peralta (1996, 1997, 2000), who described and/or illustrated in her doctoral thesis (1997) 43 species of dinoflagellate cysts from the Lower Member of the Agrio Formation. The palynostratigraphic value of terrestrial species and communities was assessed by Volkheimer \& Sepúlveda (1976) and Volkheimer \& Pöthe de Baldis (1976). Peralta \& Volkheimer (1997) discussed the palaeoenvironmental aspects of the Agrio Formation north of the Picun Leufú-Plottier High, inferred from dinoflagellate cyst assemblages, by considering the absolute abundances of individuals of a total spectrum of 24 species of dinoflagellate cysts. These same authors (Peralta \& Volkheimer, 2000) studied Early Cretaceous sea level variations, as reflected by changes in dinoflagellate cyst assemblages and organic matter components north of the Picun Leufú-Plottier High (Cerro Negro de Covunco locality, with 36 dinoflagellate cyst species present in the stratigraphic levels analized).

Ottone \& Aguirre-Urreta (2000), through a comparative analysis of dinoflagellate cysts and ammonites, proposed the existence of a marine link between the Austral and Neuquén basins 
TABLE 1. Stratigraphic chart of the Early Cretaceous. Southern Neuquén Basin. Adapted from Leanza (1999). / Cuadro estratigráfico del Cretácico Temprano. Sur de la Cuenca Neuquina. Adaptado de Leanza (1999).

\begin{tabular}{|c|c|c|c|c|c|c|}
\hline \multirow{3}{*}{$\begin{array}{l}\omega \\
0 \\
0\end{array}$} & \multirow{2}{*}{ ALBIAN } & \multicolumn{4}{|c|}{ Principal Miranic unconformity } & $\sim 100 \mathrm{Ma}$ \\
\hline & & \multirow{2}{*}{\multicolumn{2}{|c|}{ Lohan Cura Fm. }} & \multirow{2}{*}{\multicolumn{2}{|c|}{$\begin{array}{l}\text { Cullin Grande Mb. } \\
\text { Puesto Quiroga Mb. }\end{array}$}} & \\
\hline & \multirow{2}{*}{ APTIAN } & & & & & \\
\hline \multirow{4}{*}{$\begin{array}{l}0 \\
u \\
1 \\
w \\
\alpha \\
0\end{array}$} & & \multicolumn{4}{|c|}{ Intermediate Miranic unconformity } & $\sim 125 \mathrm{Ma}$ \\
\hline & BARREMIAN & & La Amarga Fm. & \multicolumn{2}{|c|}{$\begin{array}{l}\text { Piedra Parada } \mathrm{Mb} . \\
\mathrm{B} \text {.de Caichigue } \mathrm{Mb} \text {. } \\
\text { Puesto Antigual Mb. }\end{array}$} & \\
\hline & \multirow[b]{2}{*}{ HAUTERIVIAN } & \multicolumn{4}{|c|}{ Initial Miranic unconformity } & $\sim 132 \mathrm{Ma}$ \\
\hline & & \multirow{4}{*}{$\begin{array}{l}0 \\
2 \\
0 \\
\alpha \\
0\end{array}$} & \multirow{2}{*}{ Agrio Fm. } & & Transition zone & \\
\hline $\boldsymbol{\alpha}$ & \multirow{3}{*}{ VALANGINIAN } & & & & & \\
\hline \multirow{3}{*}{$\begin{array}{l}4 \\
3 \\
3 \\
0 \\
-1\end{array}$} & & & \multicolumn{3}{|c|}{ Catanlilic unconformity } & $\sim 137 \mathrm{Ma}$ \\
\hline & & & \multicolumn{3}{|c|}{ Bajada Colorada Fm. } & \\
\hline & BERRIASIAN & \multirow{3}{*}{$\begin{array}{l}\varangle \\
\mathbf{N} \\
0 \\
0 \\
\mathbf{Z} \\
\boldsymbol{W} \\
\Sigma\end{array}$} & Picún Leufú Fm. & \multirow{3}{*}{ 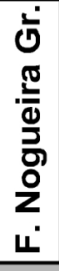 } & Limay Fm. & \\
\hline \multirow{3}{*}{ 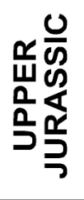 } & TITHONIAN & & Vaca Muerta Fm. & & Ortiz Fm. & \\
\hline & \multirow{2}{*}{ KIMMERIDGIAN } & & Qda. del Sapo Fm. & & Pichi P. Leufú Fm. & \\
\hline & & & Araucan & unce & formity & $\sim 153 \mathrm{Ma}$ \\
\hline
\end{tabular}

and Quattrocchio et al. (2006) established regional correlations based on well sections in northeastern Tierra del Fuego.

\section{MATERIALS AND METHODS}

The assemblages of dinoflagellate cysts were obtained by the author from grey siltstones and claystones from the lower part (Pilmatué Member) of the section of the Agrio Formation at Estancia Santa Elena locality (Neuquén Province). The preparation of the samples was carried out at the Palynology Laboratory of the Department of Geological Sciences of the University of Saskatchewan at Saskatoon, Canada. The slides are stored in the Paleopalynology Collection of the Department of Paleontology of IANIGLA / CCT - CONICET under the numbers MPLP 9039, 9040/A3 and 9041/A4 (MPLP: Mendoza-Paleopalinoteca-LaboratorioPaleopalinología). The coordinates indicated in the text correspond to the microscope Leitz Dialux 20 of the Paleopalynology Unit of IANIGLA. Those coordinates preceded by the letters SAS correspond to the Zeiss Photomikroskop of the Department of Geology of the University of Sas- katchewan at Saskatoon.The photomicrographs were obtained using Kodak T-MAX Film. The SEM micrographs have been obtained using a Philips SEM at the University of Saskatchewan.

\section{SYSTEMATICS}

A complete taxonomic list is given as an appendix at the end of the text. In this section, the description of new species of the genera Oligosphaeridium and Muderongia and taxonomic considerations on a species of the genus Muderongia are presented.

\section{Kingdom PROTOCTISTA}

Division DINOFLAGELLATA (Bütschli, 1885)

Fensome et al., 1993

Class DINOPHYCEAE Pascher, 1914

Subclass PERIDINIPHYCIDAE Fensome et al., 1993

Order GONYAULACALES Taylor, 1980

Suborder GONYAULACINEAE (Autonym)

Family GONYAULACACEAE Lindemann, 1928 Subfamily LEPTODINIOIDEAE Fensome et al., 1993 


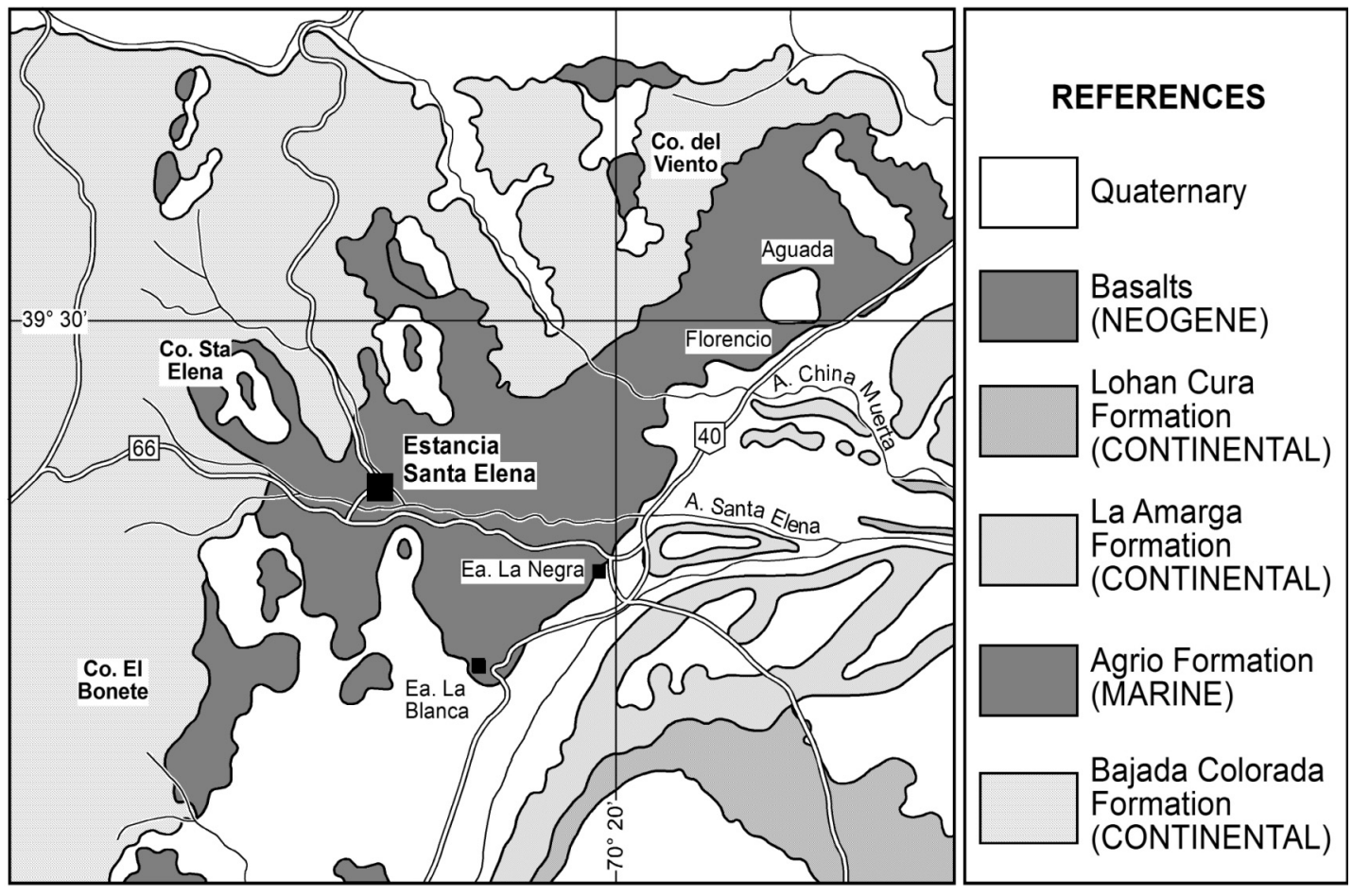

Fig. 2. Geology of the study area. Adapted from Leanza \& Hugo (1997). For age of Mesozoic formations see Table 1. / Geología del area de estudio. Adaptado de Leanza \& Hugo (1997). Para las edades de las formaciones mesozoicas ver Tabla 1.

Genus Oligosphaeridium Davey \& Williams, 1966 emend. Davey, 1982

Type: Xanthidium tubiferum var. complex White, 1842, pl. 4, fig. 11

\section{Oligosphaeridium quattrocchioae Volkheimer, sp. nov.}

(Figs. 5.H-M; 6.A-B, F-H)

Diagnosis. Oligosphaeridium quattrocchioae is differentiated essentially from other species of the genus by the distal complexity of the fenestrate processes; an Endo/Proc ratio of 2.9 (Relation between endocyst diameter and length of processes) and the fact that the antapical process is not especially large. Length of processes around one third of equatorial diameter.

Description. Skolochorate cysts of medium size, having a spherical to subspherical central body with eighteen hollow, tubiform processes and one (or two) slender, solid processes. Processes intratabular corresponding to the formula 4', 6", 6"', 1p, 1"”, 1-2s. Processes formed from periphragm only. Tubiform processes infundibular and broadening distally, aculeate to broadly cauliflorate and exhibiting perforations of variable number, size, shape and location. Apical processes markedly more slender. One sulcal process constantly present; when a second sulcal process is present, it is very slender, unbranched and flexuous. Length of processes around one-third of equatorial diameter of central body. Surface of phragma without conspicuous ornament. Archaeopyle apical (type A); operculum free.

Derivation of name. In honour of the distinguished Argentinian palynologist Dr. Mirta Quattrocchio.

Holotype. Prep. MPLP 9041 A4/2H:15.3/95.4 (MPLP: Mendoza-Paleopalinoteca-LaboratorioPaleopalinología) (fig. 6.B).

Paratype. Prep. MPLP 9041 A4/14C:26.2/94.9 (fig. 6.H).

Lodgement. Stored in the Unidad Paleopalinología del IANIGLA (Instituto Argentino de Nivología, Glaciología y Ciencias Ambientales), CCT-CONICET-Mendoza. The coordinates indi- 

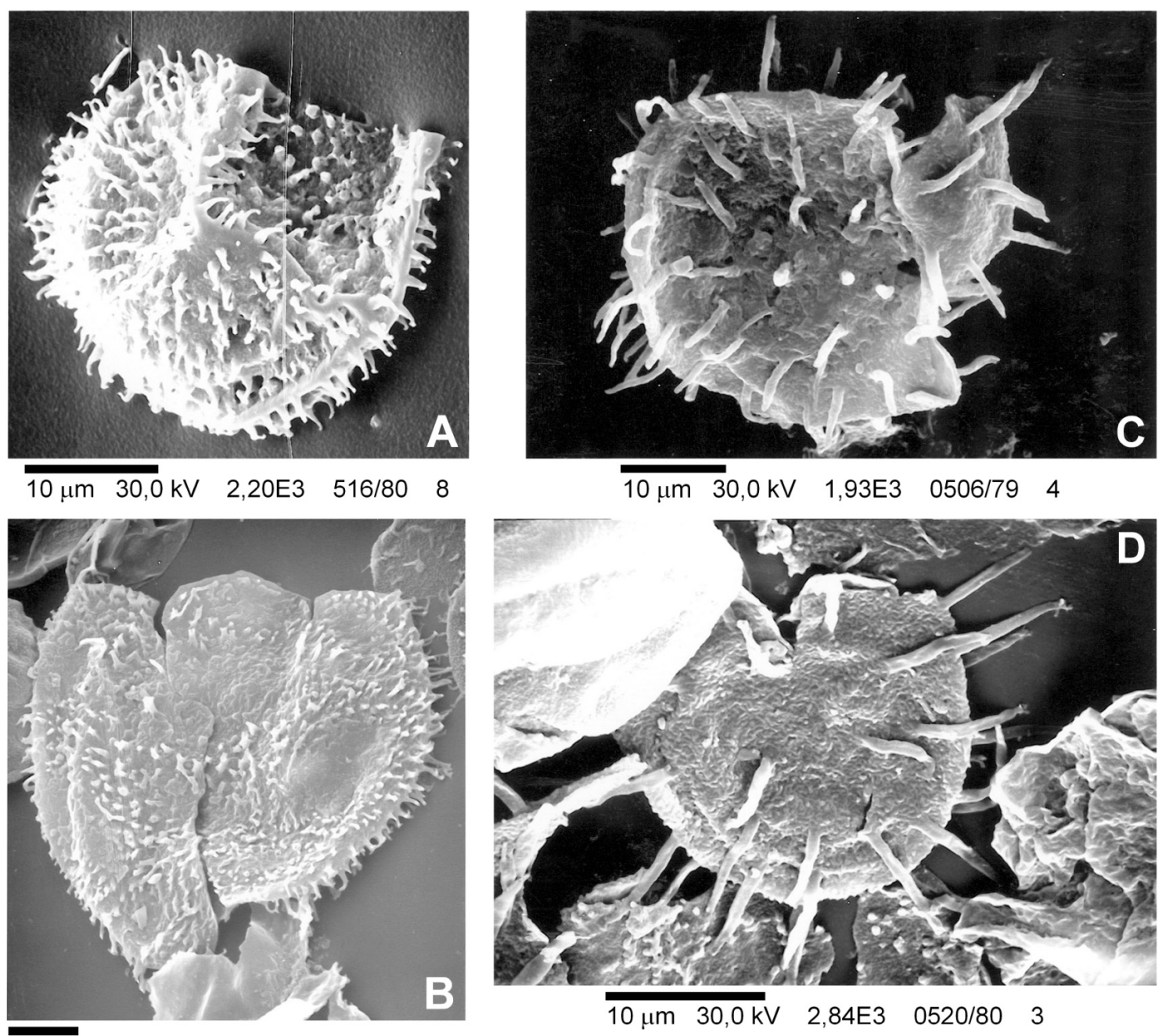

$10 \mu \mathrm{m} 30,0 \mathrm{kV} 1,25 \mathrm{E} 31699 / 30 \mathrm{VH} 8 \mathrm{~F}$
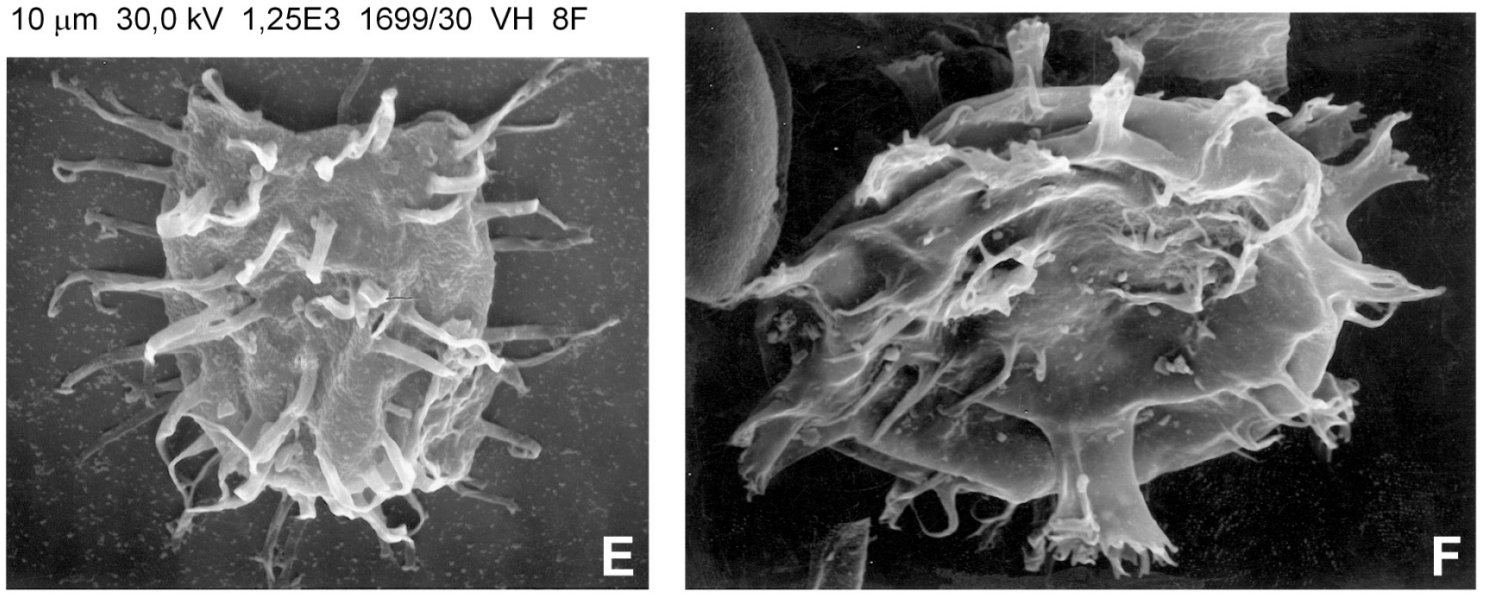

Fig. 3. All figures with SEM, from sample 9041. A-B. Circulodinium distinctum (Deflandre \& Cookson, 1955) Jansonius, 1986. C. Dapsilidinium chems (Below, 1982) Lentin \& Williams, 1985. D. Dapsilidinium cf. duma (Below, 1982) Lentin \& Williams, 1985. E. Systematophora silybum Davey, 1979a. F. Florentinia cf. interrupta Duxbury, 1980. / Todas las figuras al MEB, de la muestra MPLP 9041. 
cated correspond to the microscope Leitz Dialux 20 located at IANIGLA.

Dimensions. Holotype: maximum diameter of body: $53 \mu \mathrm{m}$. Paratype: maximum diameter of body: $58 \mu \mathrm{m}$. Range of maximum diameter of body: 44 (55) $66 \mu \mathrm{m}$ (55 specimens measured). Length of processes $13-25 \mu \mathrm{m}$.

Horizon and locality. Lower Member (=Pilmatue Member) of the Agrio Formation, 23m above the lower limit of the Formation. Estancia Santa Elena, provincial road No.66, Neuquén province, Argentina.

Stratigraphic range. Lower Member (Pilmatue Member) of the Agrio Formation (Upper Valanginian to Lower Hauterivian).

Supplementary observations. The second sulcal process is exceptionally slender and may readily escape observation. It is not constantly present; it is visible on the specimen illustrated in figure 6.2, but lacking from the specimen sketched (fig. 6.1). No indication of an anterior sulcal process was seen in any specimen. The phragma surface is laevigate to finely granulate in all specimens seen. The apical processes are more slender than those on the loisthocyst, but have comparably complex terminations. Their proportionate length could not be measured.

The degree of complexity of the process tips is highly variable. In vertical view they may appear like a ragged-edged platform with an irregular scatter of perforation of variable size; in lateral view, they are seen to be secate to cauliflorate. Two processes on the loisthocyst, l'" (Iu) and lp (X), are markedly smaller than the others; the antapical process is of a size comparable to those of the pre- and postcingular paraplates.

For comparison with other skolochorate genera of dinoflagellate cysts see figure 3. Comparison with Oligosphaeridium pulcherrimum (Deflandre and Cookson) Davey \& Williams, 1966 is close. Both species have fenestrations in the distal portions of the processes, but they differ in the Endo/Proc ratio, which is 1.9 in O. pulcherrimum, but 2.9 in O. quattrocchioae. The Endo/Proc ratio of $O$. patulum Riding and Thomas is 1.9 , similar to
O. pulcherrimum, but it presents non fenestrate processes.

O. quattrocchioae finds also a close comparison with Oligosphaeridium byersense Duane, 1997, from the Early Cretaceous (Valanginian) of the Antarctic Peninsula, which is similar in Endo/Proc ratio (2.5 vs. 2.9). However it does not have fenestrate processes and the processes of that species are larger, buccinate rather than infundibular and of even greater distal complexity, adjacent processes being sometimes linked by trabeculae. Other species, such as Oligosphaeridium complex (White) Davey and Williams, have processes proportionately larger and, though of variable complexity, showing no close matches with Oligosphaeridum quattrocchioae. Oligosphaeridium complex subsp. brevispinum Jain, 1975 (p.182, pl. 1, figure 4) has short processes, but these are proportionately much thicker than in O. quattrocchioae, giving a totally different, heavier appearance to the subspecies mentioned.

Nevertheless, the size of processes is not reliable for differentiating chorate species, as process size is not only determined by genetics and therefore might not be a good characteristic to differentiate species in one genus. As an example, size of processes in Lingulodinium polyhedrum changes when salinity of sea water does. In normal salinity sea water this species forms normal cysts with normally long processes. But, when the cysts develop in less than normal salinity, the processes are shorter (Helenes, verbal communication).

Suborder CERATIINEAE Fensome et al., 1993 Family CERATIACEAE Lindemann, 1928

Genus Muderongia Cookson \& Eisenack, 1958 emend. Monteil, 1991b

Type Species. Muderongia mcwhaei Cookson \& Eisenack, 1958, pl. 6, fig. 2

Muderongia siciliana Torricelli, 1997 (Figs. 4, A-C)

Fig. 4. A, B, C, D, F with phase contrast; E, G, H, I with interference contrast. A, B, C. Muderongia siciliana Torricelli, 1997 (magnification: x 550).A. Prep. MPLP 9041. A4/1C: SAS 104.0/13.5. B. Prep. MPLP 9041. A4/1C: SAS 105.2/13.4. C. Prep. MPLP 9041. A4/1C: SAS 101,0/13.5.. D. Achomosphaera sp. A of Norwick \& Burger, 1976 (magnification: x 1000). Prep. MPLP 9041. A4/2H: SAS 99.0/13.0. E-H. Muderongia sarjeantii $n$. sp. (magnification: 5-7: x 1000). E: Prep. MPLP 9041/A4/4C: 32.5/104.4. F. Prep. MPLP 9041:A4/4C: SAS 96.4/16.3. G. Prep. MPLP 9041. A4/4C: SAS 91.0/23.6 H. Prep. MPLP 9041. A4/2H: 15.1/93.0. I. Sentusidinium cuculliformis Davies, 1983. (magnification: x 1000).Prep. MPLP 9040: A3/10C: SAS 99.3/20.0. Las figuras A, B, C, D, F se obtuvieron con dispositivo de contraste de fases. Las figuras $\boldsymbol{E}, \boldsymbol{G}, \boldsymbol{H}, \boldsymbol{I}$ con dispositivo de contraste de interferencia. Aumentos: figuras A-C x 550, figuras $\boldsymbol{H}-\boldsymbol{I} x 1000$. 

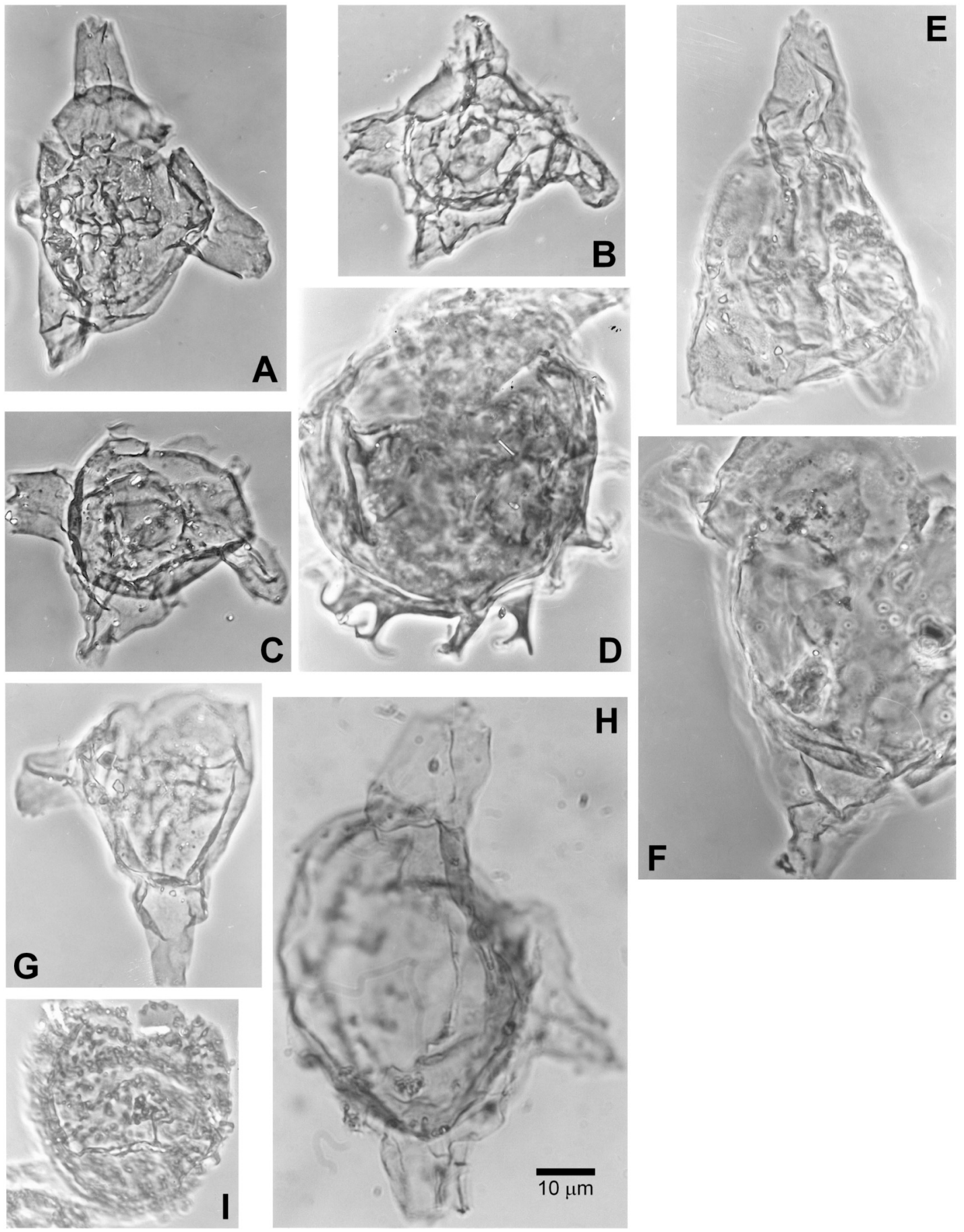

Remarks. The Argentinian specimens correspond in all essential features with those from Sicily. However, it should be noted that the operculum is by no means always free, often showing ventral attachment. The age of the Sicilian specimens (early Hauterivian) is very close to that of the Argentinian ones (latest Valanginian to earliest Hauterivian). 
Muderongia sarjeantii Volkheimer, sp. nov. (Figs. 4, E-H)

Diagnosis: A species of Muderongia in which all three horns are of comparable dimensions, very broad-based, tapering gently to blunt, rather ragged-looking tips and having a length between two-fifths and three-fifths of the length of the central body. Cingulum marked by faint lines and a slight central depression. Paratabulation not otherwise directly indicated. Endoblast almost spheroidal, but bulging into the base of the right lateral horn. Endophragm finely to coarsely granular; perifragm levigate or very finely granulate.

Description. Large cysts, ceratioid, cornucavate, with three prominent horns, apical, antapical and right lateral. The horns are broadbased, tapering gently to a blunt and irregular open tip. The apical horn is polar in position, its length less than that of the central body. The antapical horn may be polar in position or may be positioned slightly or markedly to the left of the antapical pole; its length is less than that of the central body. The right lateral horn is postcingular in position; it may be shorter than the other horns or may approach them in length. It may be straight or recurved and may exhibit a cingular notch.

Endoblast spheroidal to ellipsoidal in ambitus or bulging into the base of the right lateral horn. It may exhibit some dorsoventral flattening or may be rotund. Periblast may exhibit few low ridges bounding the cingulum, which may be shallowly concave. Alternatively, the cingulum may not be directly indicated. Sulcus and paratabulation marked by faint lines or not at all. Endophragm and periphragm laevigate or finely granulate or punctate.

Archaeopyle apical (type tA). Archaeopyle suture rounded to weakly angular; sulcal notch, when discernible, offset slightly to the left. Operculum free or attached.

Derivation of name. In honour of Dr. William Antony Swithin Sarjeant, distinguished palynologist and great author of science fiction.

Lodgement. Stored in the Unidad Paleopalinología del IANIGLA (Instituto Argentino de Nivología, Glaciología y Ciencias Ambientales), CCT-CONICET-Mendoza. The coordinates indicated correspond to the microscope Leitz Dialux 20 located at IANIGLA.

Holotype. Prep. 9041 A4/4C;32.5/104.4 MPLP (Mendoza-Paleopalinoteca-Laboratorio-Paleopalinología).

Total length: $72 \mathrm{um}$; endoblast 40x46 um. (fig. 4.E).

Paratype. Prep. 9041 A4/2H:15.1/93.1 MPLP. 4.H).

Total length: 74 um; endoblast $35 \times 48$ um (fig.

Observations. The wide, blunt and distally open horns are marking the difference from $M$. siciliana and other earlier described species of Muderongia.

Dimensions. Range of maximum total length: 69-101 $\mu \mathrm{m}$ (6 specimens measured). Specimen illustrated in figure 5.8: total legth $74 \mu \mathrm{m}$; endoblast $35 \mathrm{x} 48 \mu \mathrm{m}$

Stratigraphic range. Lower Member of the Agrio Formation (upper Valanginian to lower Hauterivian).

\section{REGIONAL COMPARISON}

The assemblage of the Lower Member of the Agrio Formation at Santa Elena is compared with other Early Cretaceous assemblages of dinoflagellate cysts from the southern hemisphere and related gondwanic areas. In order to avoid unnecessary extension of the list of References, for cita-

Fig. 5. All figures with phase contrast. A. Hystrichodinium pulchrum Deflandre 1935. (magnification: x 1000) Prep. MPLP 1940/A3/10C:30.3/96.4 . B. Achomosphaera neptuni (Eisenack, 1958a) Davey \& Williams, 1966. (magnification: x1000). Prep. MPLP 9040. A3/10C: SAS 100.0/21.8. C. Florentinia cf. interrupta Duxbury, 1980 (magnification: x 550). Prep. MPLP 9041/A4/11C. SAS 98.3/19.4. D. Heterosphaeridium? galiciae, Masure, 1988 (magnification x 550). Prep. MPLP 9041. A4/5C. SAS 92.0/16.5 . E. Pilosidinium filiatum (Davies, 1983) Courtinat, 1989 (magnification: x 550). Prep. MPLP 9041. A4/5C. SAS 96.2/16.5. F, G. Occisucysta tentoria Duxbury, 1977 (magnification: x 1000). Prep. MPLP 90.41 A4/2H: SAS 100.3/13.8. H-M. Oligosphaeridium quattrocchioae Volkheimer, sp. nov. (magnification: x 550). H. Prep. MPLP 9041. A4/4C. SAS 101.9/23.0. I. Prep. MPLP 9041. A4/5C. SAS 95.8/17.2. J. Prep. MPLP 9041. SAS 94.3/12.5. K. Prep. MPLP 9041. A4/5C. SAS 91.1/18.2.. L. Prep. MPLP 9041.A4/4C.: SAS 97.0/21.5. Todas las figuras se obtuvieron con dispositivo de contrate de fases. Aumentos: figuras $\boldsymbol{A}, \boldsymbol{B}, \boldsymbol{F}, \boldsymbol{G}, x 1000$, figuras $\boldsymbol{C}, \boldsymbol{D}, \boldsymbol{E}, \boldsymbol{H}-\boldsymbol{M}, x 550$. 

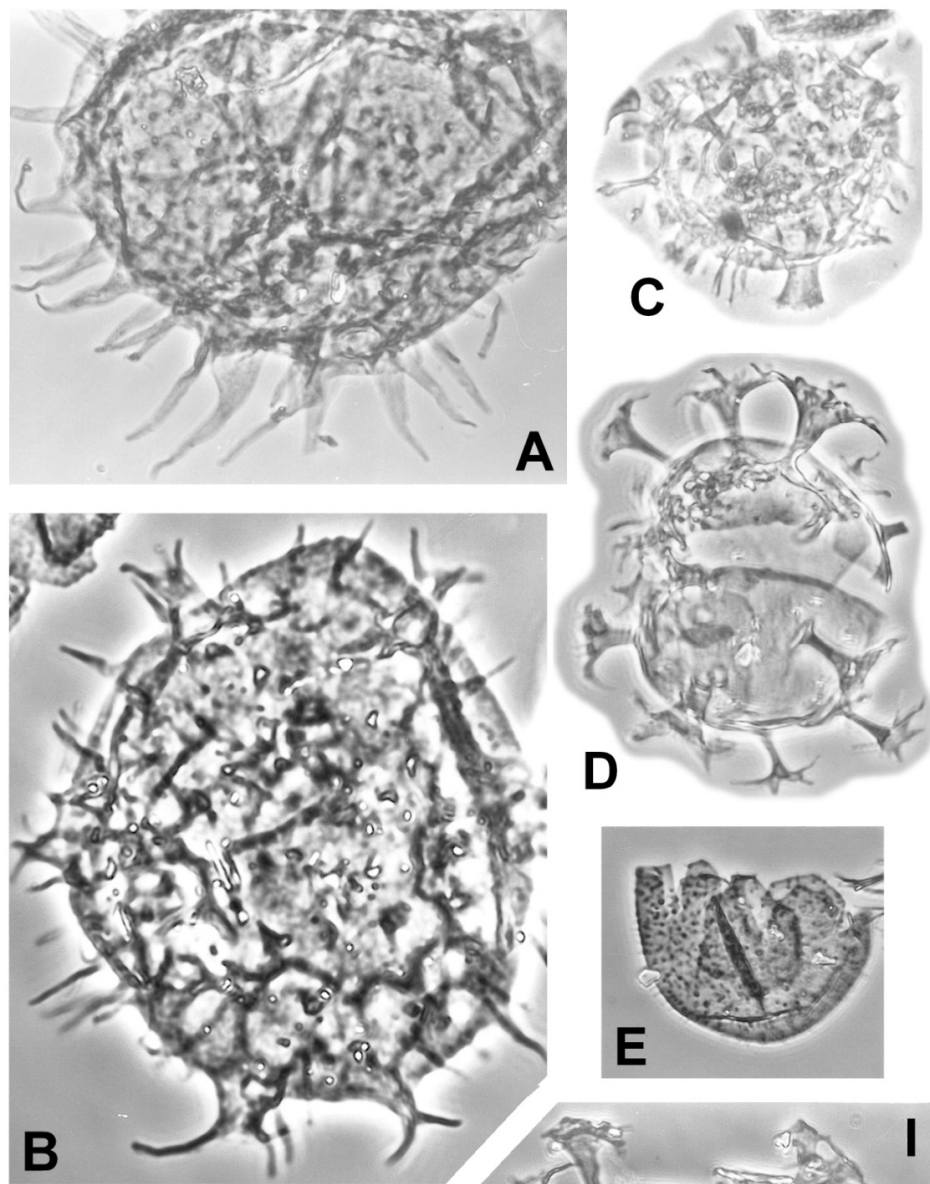

A
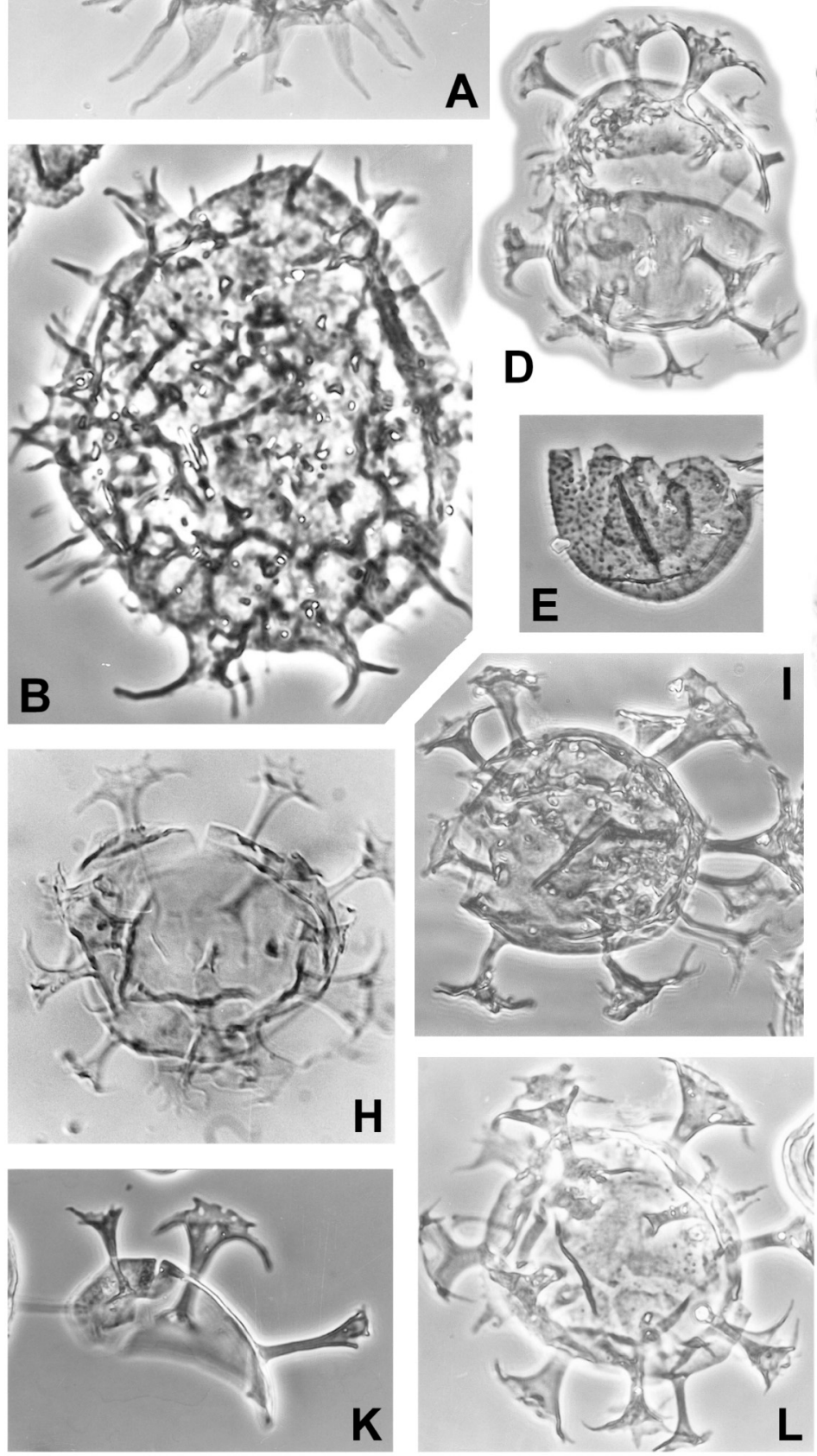
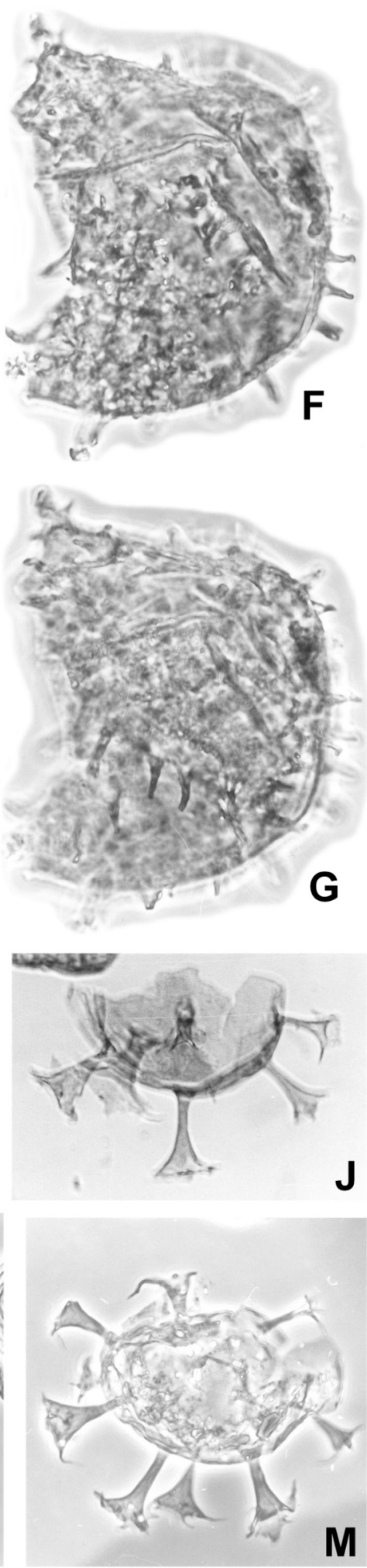
tions of papers older than 2004, on dinoflagellate cyst taxonomy, please see the list of references in Fensome \& Williams (2004).

Early Cretaceous pre-Aptian assemblages of dinoflagellate cysts have been recorded from central western Argentina (Quattrocchio \& Volkheimer, 1985, 1990; Peralta 1996, 1997, 2000; Aguirre-Urreta et al., 1999); Patagonia (Ottone \& Aguirre-Urreta, 2000); the South Atlantic Malvinas Plateau (Harris, 1976; Bair, 1984); the Indian Ocean: Mozambique Ridge east of Durban (cit. Harris, 1976); the continental shelf of South Africa (Davey, 1971); the Livingston and Snow Islands of the Antarctic Peninsula (Duane 1996); Australia (Edgell, 1964; Evans, 1966; Wiseman, 1979, 1980; Burger, 1980, 1982; Backhouse, 1987; Helby, et al., 1987); DSDP Sites 280-284, Leg 29, off Southeastern Australia and western New Zealand (Haskell \& Wilson, 1975).

\section{Central western Argentina}

Early Cretaceous dinoflagellate cysts up to 1990 were reviewed by Quattrocchio \& Volkheimer (1990). In the southern part of the Neuquén Basin, they described a Berriasian assemblage, characterized by Systematophora penicillata (Ehrenberg, 1843) Sarjeant, 1980, Sentusidinium villersense (Sarjeant, 1968) Sarjeant \& Stover, 1978, and Prolixosphaeridium sp., which also occur in Boreal associations, and an Hauterivian assemblage with Achomosphaera cf. ramulifera (Deflandre, 1937) Evitt, 1963, Cribroperidinium orthoceras (Eisenack, 1958) Davey, 1969, Gonyaulacysta sp., Hystrichosphaeridium sp., Hystrichosphaerina neuquina Quattrocchio and Volkheimer emend. Quattrocchio \& Sarjeant, 1992, Meiourogonyaulax sp., Oligosphaeridium complex (White, 1842) Davey \& Williams, 1966, Pseudoceratium cf. gochtii Neale \& Sarjeant, 1962, Scriniodinium sp. A, Sentusidinium villersense (Sarjeant, 1968) Sarjeant \& Stover, 1978, Spiniferites cf. ramosus (Ehrenberg 1838) Loeblich \& Loeblich, 1966, and Systematophora penicillata (Ehrenberg, 1843) Sarjeant, 1980.

A major contribution to the palynostratigraphic knowledge of the Early Cretaceous of the
Neuquén Basin was the doctoral thesis of Peralta (1997) on the dinoflagellate cysts of Cerro Negro and Cerro Mesa de Covunco. She described and/or illustrated 43 species of dinoflagellate cysts from the Lower Member of the Agrio Formation. The dominant species reported in that paper are Cribroperidinium orthoceras (Eisenack) Davey, 1969, Dingodinium cerviculum Cookson \& Eisenack, 1958 and Achomosphaera ramulifera. Other frequent species are Batiacasphaera asperata Backhouse, 1987, Cleistosphaeridium australe Burger, 1980, Epelidosphaeridia pentagona Morgan, 1980, Millioudodinium aichmetes Sarjeant, 1966, Oligosphaeridium complex (White) Davey \& Williams,1966, Sentusidinium sp., Spiniferites ramosus (Ehrenberg) Mantell, 1854, and Systematophora rosenfeldii Volkheimer \& Sarjeant, 1993. As stratigraphic indicators for the interval Valanginian-Barremian she considers the following species: Cassiculosphaeridia magna Davey, 1974, Cribroperidinium muderogense (Cookson and Eisenack) Davey, 1969, Dinogymnium acuminatum Evitt et al., 1967, Oligosphaeridium nannum Davey, 1974, Millioudodinium aichmetes (Sarjeant) Stover \& Evitt, 1978, Pseudoceratium gochtii Pocock, 1962, Systematophora rosenfeldii Volkheimer \& Sarjeant, 1993, and Callaiosphaeridium asymmetricum (Deflandre and Courteville) Davey \& Williams, 1966. In accordance, an early Hauterivian age of the assemblage of dinoflagellate cysts is indicated by the association with guide ammonites: Acanthodiscus vaceki (Neumayer and Uhlig), which corresponds to the Lyticoceras pseudoregale Zone (Leanza, 1981).

\section{Patagonia}

The late Valanginian to Hauterivian and Barremian Springhill Formation of southern Patagonia contains, in addition to an abundant (and prevailing) terrestrial microflora, an assemblage of dinoflagellate cysts surprisingly similar to that of the Agrio Formation of the Neuquén Basin. Based on this similarity, Ottone \& Aguirre-Urreta (2000) postulated the presence of a marine corridor between the Austral Basin (Patagonia) and the Neuquén Basin, at least during

Fig. 6. A-B. Oligosphaeridium quattrocchioae Volkheimer, sp. nov. A. Sketch. B. Holotype. Observe the slender sulcal process and the adhering operculum. Prep. MPLP 9041. A4/2H:15.3/95.4. C-D. Stiphrosphaeridium dictyophorum (Cookson \& Eisenack) Davey 1982. C. Prep. MPLP 9041. A4/5C. SAS 96.3/23.0 D. Prep. MPLP 9041. A4/5C. SAS 92.6/18.8. E. Stiphrosphaeridium sp. Prep. MPLP 9041.A4/5C. SAS 93.7/16.2. F-H. Oligosphaeridium quattrocchioae Volkheimer, sp. nov.(all magnifications x 550; less the operculum on Fig. 6..G: x 1000). F. Prep. MPLP 9040. A3/10C. SAS 102.0/10.0. H. Prep. MPLP 9041. A4/14C: 26.2/94.9. A. Dibujo. B. . Holotipo. Obsérvese el delgado proceso sulcal y el opérculo adherido. Aumentos x 550, con excepción del opérculo de la figura 6G: $x 1000$. 

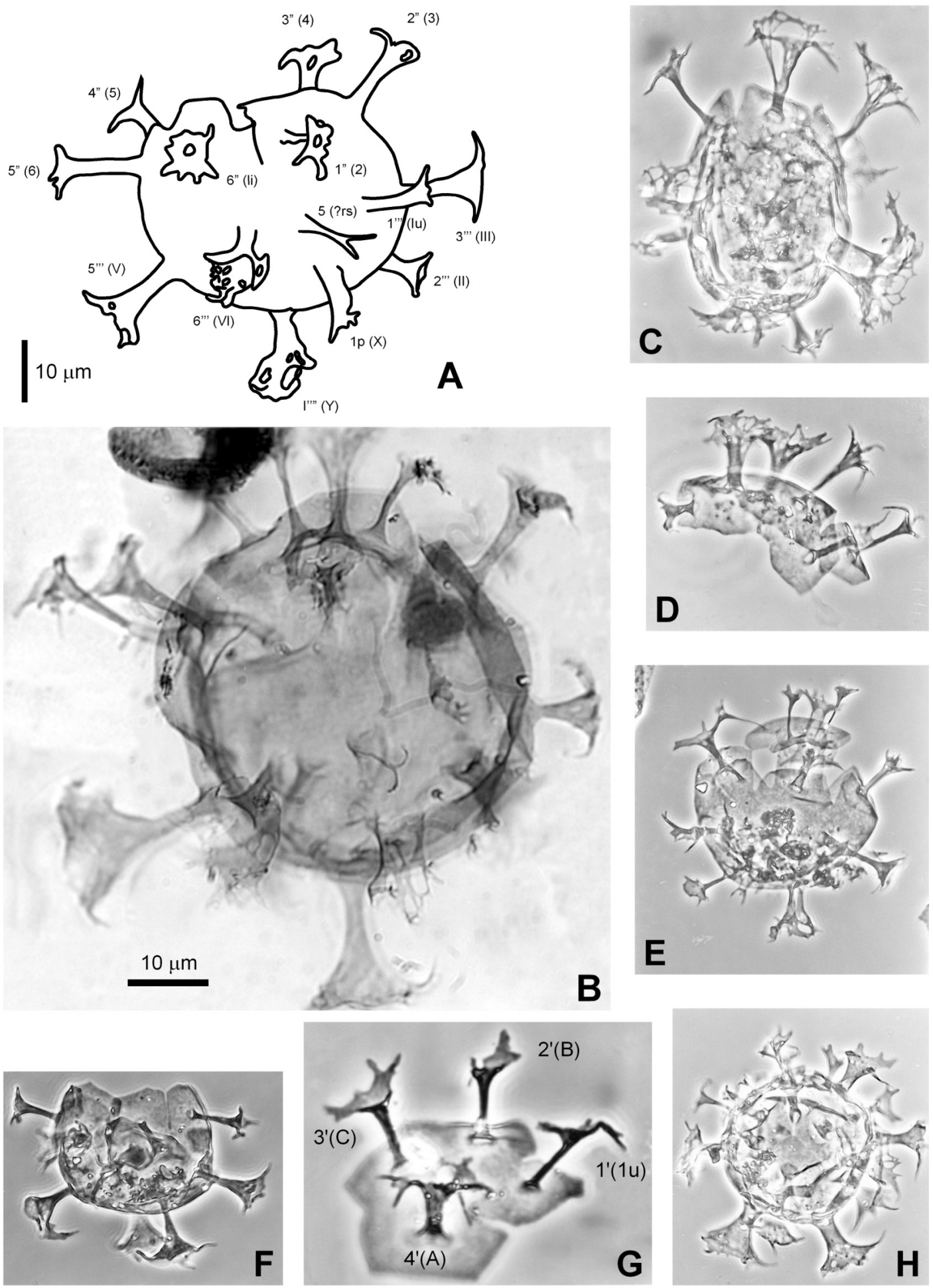

I'"' $(Y)$
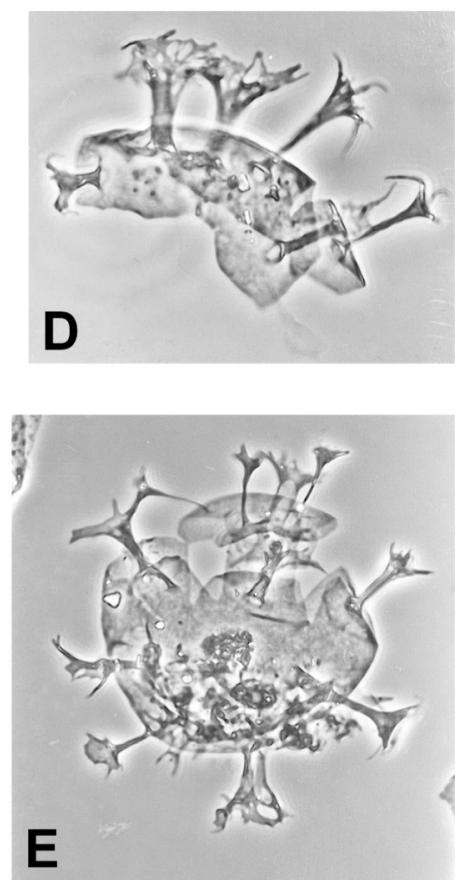

B
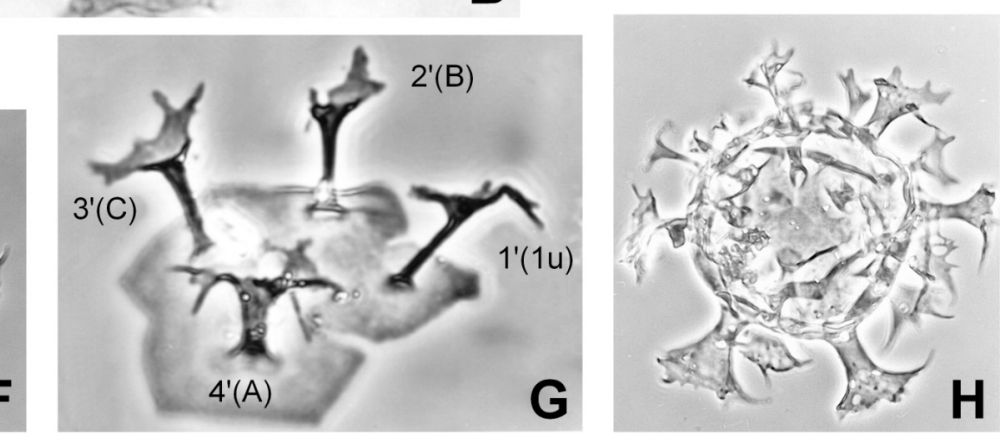

the Hauterivian and early Barremian. They cite (and partly illustrate) an assemblage composed by Apteodinium sp., Biorbifera (?) sp., Circulodinium distinctum Deflandre and Cookson, Cribroperi- dinium muderongense (Cookson and Eisenack) Davey, Exochosphaeridium? sp., Gonyaulacysta sp., Hystrichosphaeridium sp. cf. H. tubiferum (Ehrenberg) Deflandre, Muderongia australis 
Table 2. Stratigraphic position and lithology of the palynologic samples studied. Agrio Formation, Estancia Santa Elena, Neuquén province, Argentina. / Posición estratigráfica y litología de las muestras palinológicas estudiadas. Formación Agrio, Estancia Santa Elena, provincia de Neuquén, Argentina.

\begin{tabular}{|c|c|c|c|c|}
\hline $\begin{array}{c}\text { \# of } \\
\text { sample }\end{array}$ & $\begin{array}{c}\text { stratigraphic } \\
\text { distance above } \\
\text { the upper limit } \\
\text { of Bajada } \\
\text { Colorada Fm. }\end{array}$ & lithology & preservation & $\begin{array}{c}\text { \# Paleopalyn. } \\
\text { Laboratory } \\
\text { IANIGLA }\end{array}$ \\
\hline $020382 / 9$ & $35 \mathrm{~m}$ & $\begin{array}{c}\text { siltstone, } \\
\text { gray }\end{array}$ & fair & 9043 \\
\hline $020382 / 8$ & $29 \mathrm{~m}$ & $\begin{array}{c}\text { siltstone, } \\
\text { gray }\end{array}$ & fair & 9042 \\
\hline $020382 / 7$ & $23 \mathrm{~m}$ & $\begin{array}{c}\text { siltstone, } \\
\text { gray-brown }\end{array}$ & well & $9041 / \mathrm{A4}$ \\
\hline $020382 / 6$ & $19 \mathrm{~m}$ & $\begin{array}{c}\text { siltstone, } \\
\text { gray-brown }\end{array}$ & well & $9040 / \mathrm{A3}$ \\
\hline $020382 / 5$ & $15 \mathrm{~m}$ & $\begin{array}{c}\text { claystone } \\
\text { gray }\end{array}$ & well & 9039 \\
\hline
\end{tabular}

Table 3. Comparison of Oligosphaeridium quattrocchioae with similar species. / Comparación de Oligosphaeridium quattrocchioae con especies similares.

\begin{tabular}{|l|c|l|}
\hline \multicolumn{1}{|c|}{ Taxon } & $\begin{array}{c}\text { Endocyst } / \\
\text { Processes }\end{array}$ & \multicolumn{1}{c|}{ Shape of processes } \\
\hline O. pulcherrimum & $(58 / 30=1.9)$ & Multifurcate, only distal fenestration \\
\hline O. quattrocchioae & $(55 / 19=2.9)$ & Multifurcate, fenestration all over \\
\hline O. byersense & $(56 / 22=2.5)$ & Multifurcate, non fenestrate \\
\hline O. patulum & $(58 / 30=1.9)$ & Spiny, non fenestrate \\
\hline Stiphr. anthophorum & $(70 / 50=1.4)$ & Non furcated, distal trabeculae, fenestrate \\
\hline
\end{tabular}

Helby emend. Monteil, Muderongia crucis Neale and Sarjeant emend. Monteil, Muderongia staurota Sarjeant emend. Monteil, Oligosphaeridium complex (White) Davey and Williams, Prolixosphaeridium sp., Systematophora rosenfeldii Volkheimer and Sarjeant.

These data are derived from Estancia El Salitral locality and the combined evidence from the terrestrial microflora and the assemblage of dinoflagellate cysts indicates a Hauterivian to lower Barremian age (Ottone \& Aguirre-Urreta, 2000).

Quattrocchio et al. (2006) studied well sections of northeastern Tierra del Fuego, Argentina. They established a correlation with the Interulobites-Foraminisporis Assemblage Zone (Upper ValanginianUpper Hauterivian) of Austral Patagonia and with the Upper Valanginian-Lower Aptian Cyclusphaera psilata-Classopollis Zone of the Neuquén Basin.

\section{South Atlantic Malvinas Plateau}

Harris (1976) studied cores from Deep Sea Drilling Sites 327, 328 and 330, situated on the Malvinas Plateau. He mentions a very strong southern hemisphere component, particulary in the marine elements, which show similarities with western Australia and the Indian Ocean. Common elements with the Agrio Formation are Tenua hystrix Eisenack, Cribroperidinium orthoceras (Eisenack) Davey, Dingodinium cerviculum Cookson and Eisenack, Prolixosphaeridium sp., Spiniferites sp. cf. S. ramosus (Ehrenberg) Mantell and Chytroeisphaeridia sp. 


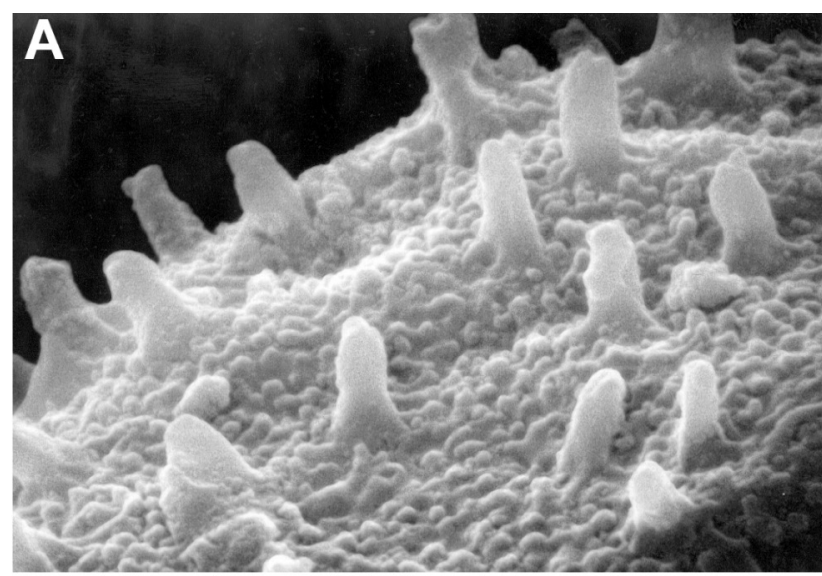

$10 \mu \mathrm{m} \quad 30,0 \mathrm{kV} \quad 1,09 \mathrm{E} 3 \quad 0981 / 93 \quad 3 \mathrm{DL}$

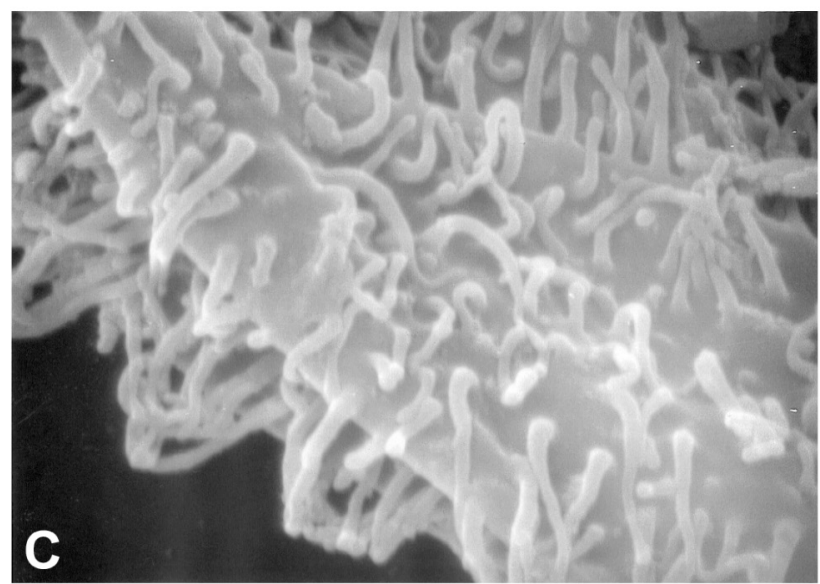

\begin{tabular}{llllll}
\hline $10 \mu \mathrm{m}$ & $30,0 \mathrm{kV}$ & $9,60 \mathrm{E} 3$ & $1715 / 31$ & $\mathrm{VH}$ & $8 \mathrm{~F}$
\end{tabular}

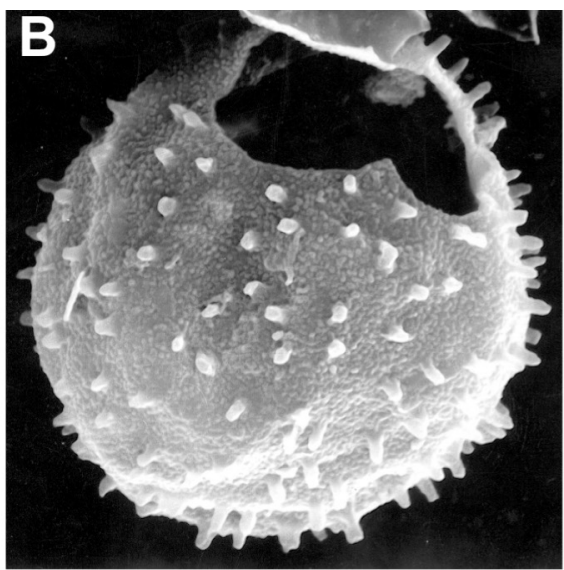

$10 \mu \mathrm{m} \mathrm{30,0} \mathrm{kV} \mathrm{2,84E3} \mathrm{0980/93} \mathrm{3DL}$

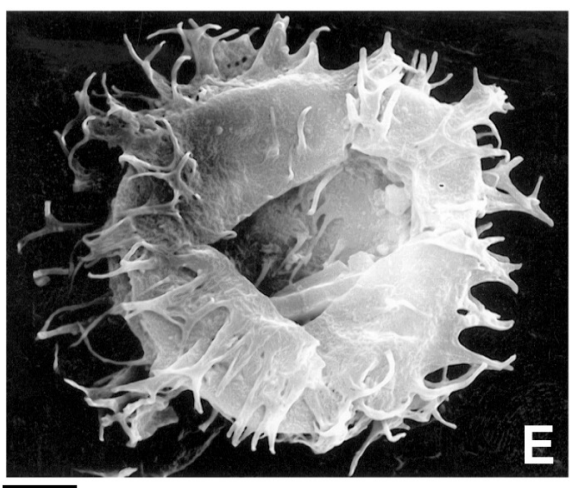

$10 \mu \mathrm{m} 30,0 \mathrm{kV} 1,05 \mathrm{E} 31624 / 25 \mathrm{VH} 8 \mathrm{D}$

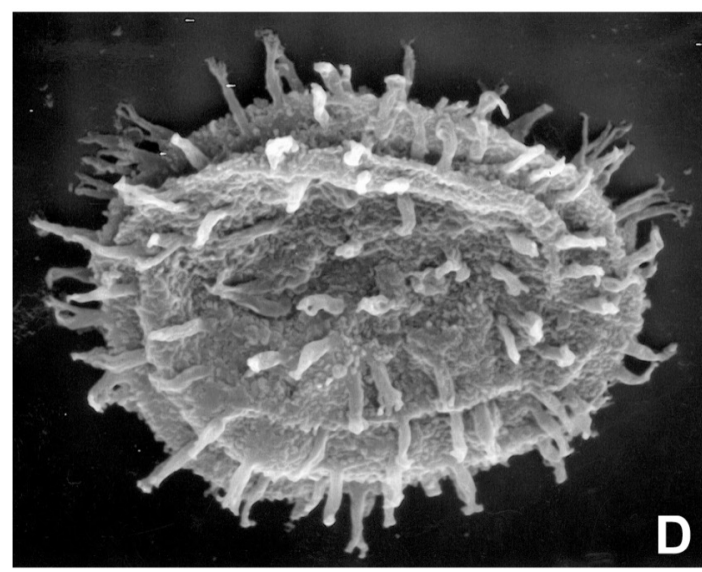

$10 \mathrm{um} 30.0 \mathrm{kV}$

$2.72 \mathrm{E} 3$

$1965 / 30$ VH $8 F$

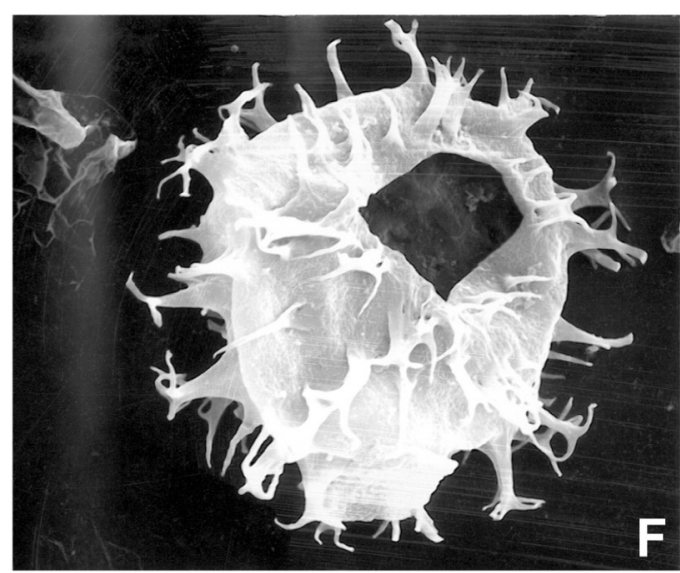

$10 \mathrm{um} 30.0 \mathrm{kV} 1.05 \mathrm{E} 31624 / 25 \mathrm{VH} 8 \mathrm{D}$

Fig. 7. All figures with SEM, from sample MPLP 9041 A-B. ?Pervosphaeridium sp. Figure 7A is a magnification of Fig. 7 B. C-D. Protoellipsodinium sp. E. Spiniferites lenzii Below, 1982. F. Spiniferites cf. S. speetonensis Duxbury, 1980. / Todas las figuras con MEB, de la muestra MPLP 9041. La figura 7A es una ampliación de la figura $\boldsymbol{7 B}$. 


\section{Antarctic Peninsula: Livingston and Snow Islands}

The Byers Group (Late Jurassic-Early Cretaceous) of Livingston and Snow islands, Antarctic Peninsula were deposited in a fore-arc setting and is comprised by the Late Jurassic Anchorage Formation, the Berriasian President Beaches Formation, the Valanginian Chester Cone Formation and overlying, non-differentiated non-marine strata. Duane (1996) emphasizes the strong affiliation of the Byers Group palynoflora to those from the Mesozoic of Australia and southern South America and the marked provincialism within the Valanginian marine microplankton content.

\section{Australia}

The assemblage of dinoflagellate cysts from the lowermost part of the Agrio Formation (Neuquén Basin) can be correlated with part of the Australian Muderongia Superzone and, within this superzone, with the Phoberocysta burgeri Interval Zone (Helby et al., 1987), which extends from the oldest occurrence of Phoberocysta burgeri (at the base) and apparently the oldest occurrences of Muderongia spp. to the oldest occurrence of Dingodinium cerviculum. Significant forms within the Interval Zone mentioned are Kaiwaradinium scrutillinum Backhouse, Systematophora areolata, Klement, Senoniasphaera tabulata Backhouse and Helby and Muderongia testudinaria Burger. The suggested age is Late Valanginian to Early Hauterivian (Helby et al., 1987). The Reference section is the Mullalloo-1 well, 821-861m, Lederville Formation.

\section{PALEOBIOGEOGRAPHIC AND PALEOGEO- GRAPHIC IMPLICATIONS OF THE ASSEM- BLAGE OF DINOFLAGELLATE CYSTS OF THE AGRIO FORMATION AT SANTA ELENA LOCALITY}

Of a total number of 27 morphotypes studied at the species level, 13 are from NW and W Europe, six from the Tethyan Realm, four from Australia and two from Canada.
The cosmopolitan character of the assemblage of marine dinoflagellate cysts of the Agrio Formation at Estancia Santa Elena locality indicates for the late Valanginian and early Hauterivian an open marine connection between the Neuquén Basin, the Tethyan Realm and western/northwestern Europe. It also indicates a low gradient of paleotemperatures between paleoequator and poles.

Based on ammonite faunas, Aguirre-Urreta et al. (1999) established a correlation of the Agrio Formation with the column of the western Tethys, complemented by studies on palynomorphs and calcareous nannofossils. Their results show that an open marine connection, as above mentioned, continued through the Hauterivian and Barremian. In a later contribution, Aguirre-Urreta et $a l$. (2008) show that early in the Cretaceous the ammonites are represented in the Neuquén Basin by six families (belonging to 20 genera/subgenera) of tethyan affinities and that paleotemperatures in the Neuquén Basin were similar to those in the Tethys.

\section{STRATIGRAPHIC RANGE OF THE SPECIES OF DINOFLAGELLATE CYSTS PRESENT IN THE LOWERMOST SECTION OF THE AGRIO FORMATION AT ESTANCIA SANTA ELENA LOCALITY (TABLE 4)}

Only two of the morphospecies present were originally described in Jurassic strata: Prolixosphaeridium anasillum Erkmen \& Sarjeant, 1980 from the Late Callovian (Lamberti Zone) of Yorkshire and Stiphrosphaeridium dictyophorum (Cookson and Eisenack) Davey 1982 from the Late Jurassic of Australia. Cometodinium habibii Monteil, with a holotype from the Berriasian stratotype section in France and Pilosidinium filiatum (Davies) Courtinat, 1989 from the Upper Deer Bay Formation (Berriasian-Valanginian of Arctic Canada) have both a Late Jurassic to Valanginian distribution. The remaining 18 morphotypes are exclusively Cretaceous forms: 15 of them limited to the Early Cretaceous and three extending into the Late Cretaceous, as indicated

Fig. 8. All figures with phase contrast. A-B. Protoellipsodinium cf. seghire Below, 1981. A. Prep. MPLP 9040. A3/10C. SAS 107.5/18.2. B. Prep. 9040.A3/2H.SAS 100.0/3.4. C-F. Pseudoceratium pelliferum Gocht, $1957 . C$. Prep. MPLP 9041 A4/4C. SAS 91.1/11.2 . D. Prep. MPLP 9041/A4/4C. SAS 97.5/16.8. E. Prep. MPLP 9040. A3/ 10C. SAS 100.1/19.0. F. Prep. MPLP 9041.A4/4C.SAS 96.9/16.0. G. Tanyosphaeridium boletus Davey, 1974.Prep. MPLP 9041/A4/4C. SAS 90.7/10.0. H. Cyclonephelium cf. vannophorum Davey, 1969. Prep. MPLP 9041. A4/5C. SAS 90.4/22.7. I-J. Cometodinium sp. cf. C. habibii Monteil, 1991a. I. MPLP 9041. A4/4C SAS 98.5/14.7. J. MPLP 9041. A4/4C. SAS 98.0/16.0. K-L. Tanyosphaeridium isocalamum (Deflandre \& Cookson, 1955) Davey \& Williams, 1969. K. MPLP 9041.A4/11C. SAS 95.7/20.0. L. MPLP 9041. A4/11C. SAS 97.0/220.0. Magnifications: A-B, F-L: x 1000, C-E: x 500. / Todas las figuras con contraste de fase. Aumentos: A-B, F-L: $x$ 1000, C-E: $x 500$. 

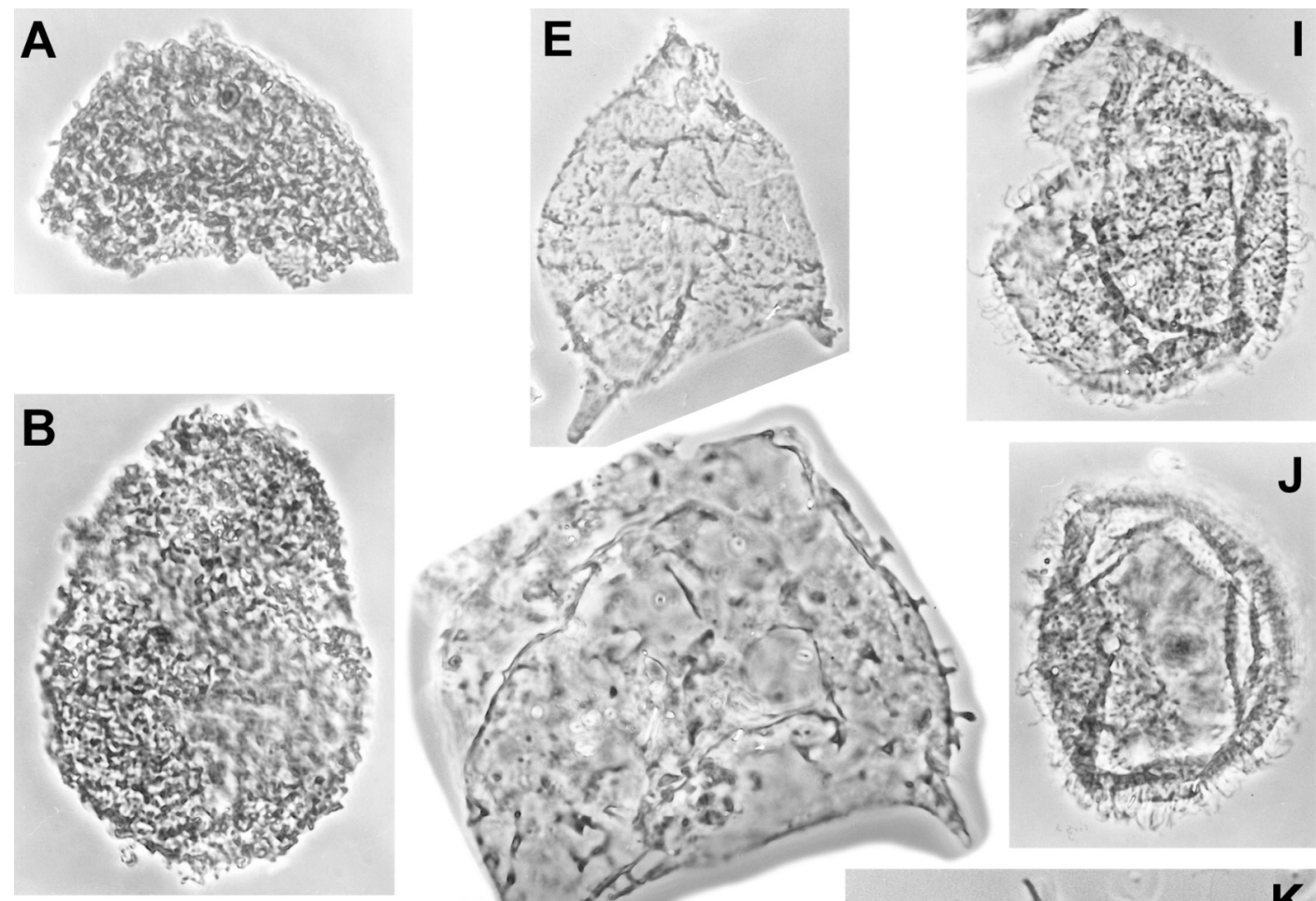

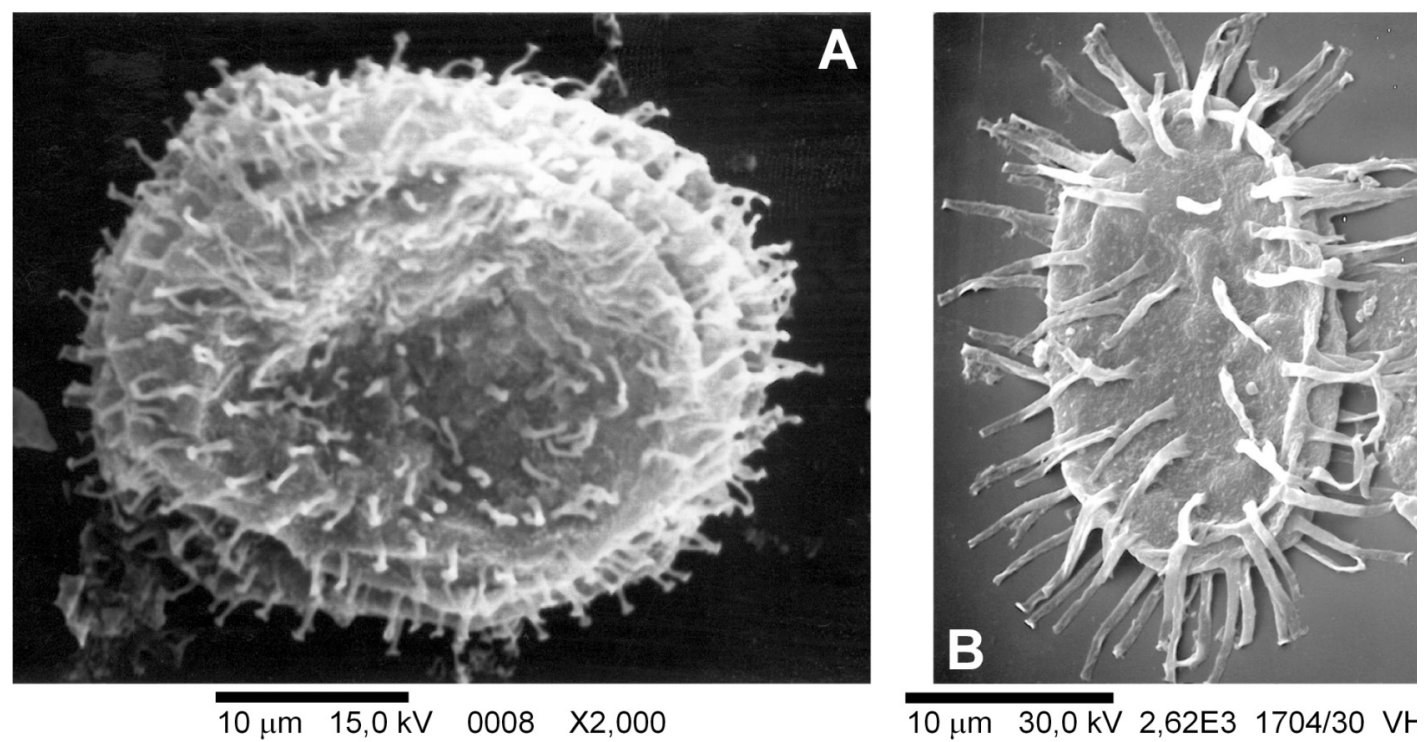

Fig. 9. All figures with SEM, from sample MPLP 9041. A. Tenua cf. hystrix Eisenack emend. Sarjeant, 1985. B. Prolixosphaeridium cf. anasillum Erkmen \& Sarjeant, 1980. / Todas las figuras con MEB, de la muestra MPLP 9041

Table 4. Stratigraphic range of dinoflagellate cyst species present in the lowermost section of the Agrio Formation at Estancia Santa Elena locality. / Distribución estratigráfica de las especies de quistes de dinoflagelados presentes en la parte inferior de la Formación Agrio en la localidad Estancia Santa Elena.

\begin{tabular}{|c|c|c|c|c|c|c|c|c|c|c|c|c|}
\hline \multirow{3}{*}{ Taxon } & \multirow{3}{*}{ Obs. } & \multicolumn{4}{|c|}{ Jurassic } & \multicolumn{7}{|c|}{ Cretaceous } \\
\hline & & \multirow{2}{*}{\begin{tabular}{|l|} 
Mid \\
Call
\end{tabular}} & \multicolumn{3}{|c|}{ Late } & \multicolumn{6}{|c|}{ Early } & \multirow{2}{*}{ Late } \\
\hline & & & Oxf & $\mathrm{Ki}$ & Tit & Berr & Val & $\mathrm{Hau}$ & Barr & Apt & Alb & \\
\hline Prolixosphaeridium anasillum & cf. & & & & & & & & & & & \\
\hline \multicolumn{13}{|l|}{ Pilosidinium filiatum } \\
\hline Cometodinium habibii & cf. & & & & & & & & II & 10 & $\mathbf{I}$ & \\
\hline \multicolumn{13}{|l|}{ Stiphrosphaeridium dictyophorum } \\
\hline \multicolumn{13}{|l|}{ Sentusidinium cuculliformis } \\
\hline \multicolumn{13}{|l|}{ Occisucysta tentoria } \\
\hline \multicolumn{13}{|l|}{ Pseudoceratium pelliferum } \\
\hline \multicolumn{13}{|l|}{ Oligosphaeridium quattrocchioae } \\
\hline \multicolumn{13}{|l|}{ Muderongia sarjeantii } \\
\hline \multicolumn{13}{|l|}{ Muderongia siciliana } \\
\hline \multicolumn{13}{|l|}{ Dapsilidinium chems } \\
\hline Spiniferites speetonensis & cf. & & & & & & & & & & & \\
\hline \multicolumn{13}{|l|}{ Systematophora silybum } \\
\hline \multicolumn{13}{|l|}{ Tanyosphaeridium boletus } \\
\hline \multicolumn{13}{|l|}{ Tanyosphaeridium isocalamum } \\
\hline Protoellipsodinium seghire & cf. & & & & & & & III & III & III & & \\
\hline \multicolumn{13}{|l|}{ Spiniferites lenzii } \\
\hline Dapsilidinium duma & cf. & & & & & & & & & & 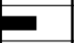 & \\
\hline \multicolumn{13}{|l|}{ Florentinia? neptuni } \\
\hline Cyclonephelium vannophorum & cf. & & & & & & & $\mathbf{1 0 0}$ & III & Iat & 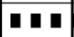 & 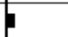 \\
\hline \multicolumn{13}{|l|}{ Hystrichodinium pulchrum } \\
\hline Circulodinium distinctum & & & & & & & & 100 & II I & II & III & II \\
\hline
\end{tabular}


on Table 4. The latter are Cyclonephelium vannophorum Davey extending to the Cenomanian, Hystrichodinium pulchrum Deflandre and Circulodinium distinctum (Deflandre and Cookson) Jansonius, both with holotypes of Senonian age. The known distributions of the two endemic for$\mathrm{ms}$ Oligosphaeridium quattrocchioae nov. sp. and Muderongia sarjeantii nov. sp. are limited to the late Valanginian and early Hauterivian strata of the study area.

\section{CONCLUSIONS}

1. In an assemblage of dinoflagellate cysts from the Pilmatue Member of the Early Cretaceous Agrio Formation (Neuquén Basin) 30 marine species are recognized.

2. The new species Oligosphaeridium quattrocchioae and Muderongia sarjeantii are endemic.

3. Comparison of the dinoflagellate cyst assemblage of the Pilmatue Member of the Agrio Formation at Santa Elena locality with other Early Cretaceous assemblages from the southern hemisphere, the Tethyan realm and northwestern Europe, shows the cosmopolitan character of most components of the assemblage here studied and indicates a low gradient of temperatures between the paleoequator and poles during Early Cretaceous times.

\section{ACKNOWLEDGEMENTS}

The fieldwork was supported by the Argentinean Research Council: Consejo Nacional de Investigaciones Científicas y Técnicas (CONICET). Part of the authors research was performed during a stay in the Department of Geological Sciences of the University of Saskatchewan, supported by the National Research Council of Canada. The technical aid of J.W.C. Sharp, Ngat Mee Choo (Department of Geological Sciences, University of Saskatchewan), Rafael Bottero (IANIGLACONICET) and D.L. Melendi (Museo Argentino de Ciencias Naturales "B. Rivadavia) are gratefully acknowledged. This paper is a contribution to the proyect PIP-CONICET 5222. Many thanks to Drs. J. Helenes Escamilla, J.B. Riding, M. Quattrocchio and M. Prámparo for their helpful comments and corrections of the manuscript, to P. Narváez and Gregory Hoke for their help in the final redaction of the paper.

The author thanks Dr. W. A. S. Sarjeant for advise during a stay in Saskatchewan and during his visit to Argentina in 2000. This work was originally planned as a joint publication with him, who unfortunately died on $8^{\text {th }}$ of July, 2002. This paper is written in memory of my good friend William Antony Swithin Sarjeant.

\section{BIBLIOGRAPHY}

Aguirre-Urreta, M.B., A. Concheyro, M. Lorenzo, E.G. Ottone \& P.F. Rawson. 1999. Advances in the biostratigraphy of the Agrio Formation (Lower Cretaceous) of the Neuquén Basin, Argentina: ammonites, palynomorphs and calcareous nannofossils. Palaeogeography, Palaeoclimatology, Palaeoecology 150: 33-47.

Aguirre-Urreta, M. B., S. Casadío, M. Cichowolski, D.G. Lazo \& D.L. Rodríguez. 2008. Afinidades paleobiogeográficas de los invertebrados cretácicos de la Cuenca Neuquina. Ameghiniana 45 (3): 591-611.

Backhouse, J. 1987. Late Jurassic and Early Cretaceous palynology of the Pearth Basin, Western Australia. Bulletin of the Geological Survey of Western Australia 135: 1-233.

Bair, J. 1984. Palynology of some Lower Cretaceous sediments from the Malvinas Area, South Atlantic. $3^{\circ}$ Congreso Latinoamericano de Paleontología (Oaxtepec, México, 1984), Memoria: 280-288.

Below, R. 1981. Dinoflagellaten-Zysten aus dem oberen Hauterive bis unteren Cenoman Süd-West-Marokkos. Palaeontographica, Abteilung B., v. 176: 1-145, pl. 1-15.

Below, R. 1982. Scolochorate Zysten der Gonyaulacaceae (Dinophyceae) aus der Unterkreide Marokkos. Palaeontographica, Abteilung B 182: 1-51.

Brenner, G.J. 1976. Middle Cretaceous Floral Provinces and Early Migrations of Angiosperms. In: Beck, C.B. (Edit.) Origin and Early Evolution of Angiosperms:23-47, Columbia University Press. New York.

Brinkmann, H.D. 1994. Facies and sequences of the Agrio Formation (Lower Cretaceous) in the central and southern Neuquén Basin, Argentina. Zentralblatt für Geologie und Paläontologie, Teil 1: 309317.

Burger, D. 1980. Early Cretaceous (Neocomian) microplancton from the Carpentaria Basin, northern Queensland. Alcheringa 4: 263-279.

Burger, D. 1982. A basal Cretaceous dinoflagellate suite from northeastern Australia. Palynology 6: 161-192.

Bütschli, O. 1885. Erster Band. Protozoa. In: Dr. H. G. Bronn's Klassen und Ordnungen des Thier-Reichs, wissenschaftlich dargestellt in Word und Bild; $p$. 865-1088; C. F. Winter'sche Verlagsbuchhandlung, Leipzig and Heidelberg, Germany.

Concheyro, A., M. Lescano, A. Carames \& S. Ballent. 2009. Micropaleontología de la Formación Agrio (Cretácico Inferior) en distintos sectores de la $\mathrm{Cu}$ enca Neuquina. Revista de la Asociación Geológica Argentina 65 (2): 342-361.

Cookson, I.C. \& Eisenack, A. 1958. Mikroplankton from Australian and New Guinea Upper Mesozoic sediments. Proceedings of the Royal Society of Victoria, v. 70, no. 1, p. 19-79, pl. 1-12.

Courtinat, B. 1989. Les organoclasts des formations lithologiques du Malm dans le Jura méridional: 
systematique, biostratigraphie et elements d' interpretation paleoecologique. Documents des Laboratoires de Géologie de la Faculté des Sciences de Lyon 105: 1-361.

Davey, R.J. 1969. Non-calcareous microplancton from the Cenomanian of England, northern France and North America. Part I. Bulletin of the British Museum (Natural History) Geology 17: 103-180.

Davey, R.J. 1971. Palynology and paleoenvironmental studies with special reference to the continental shelf sediments of South Africa. Proceedings II Planktonic Conference, Roma 1970: 331-347.

Davey, R.J. 1974. Dinoflagellate cysts of the Barremian of the Speeton Clay, England. Symposium on Stratigraphic Palynology, Birbal Sahni Institute of Palaeobotany, Special Publication 3: 41-75.

Davey, R.J. 1979. Two new Early Cretaceous dinocyst species from the northern North Sea.. Palaeontology, v. 22: 427-437, pl. 48-50.

Davey, R.J. 1982. Dinocyst stratigraphy of the latest Jurassic to Early Cretaceous of the Haldager No. 1 borehole, Denmark. Geological Survey of Denmark, Series B 6: 1-57.

Davey, R.J. \& G.L. Williams. 1966. V. The genus Hystrichosphaeridium and its allies. In: Davey, R.J., Downie, C., Sarjeant, W.A.S. and Williams, G.L. Studies on Mesozoic and Cainozoic dinoflagellate cysts; British Museum (Natural History) Geology, Bulletin, Supplement 3, p. 53-106.

Davies, E.H. 1983. The dinoflagellate Oppel-Zonation of the Jurassic-Lower Cretaceous sequence in the Sverdrup Basin, Arctic Canada. Bulletin of the Geological Survey of Canada 359: 1-59.

Deflandre, G. 1935. Considérations biologiques sur les microorganisms d'origine planctonique conservés dans les silex de la craie. Bulletin biologique dee la France et de la Belgique, v. 69, p. 213-244, pl. 5-9.

Deflandre, G. 1937. Microfossiles des silex crétacés. Deuxième partie. Flagellés incertae sedis. Hystrichosphaeridés. Sarcodinés. Organismos divers. Annales de paléontologie, v. 26, p. 51-103 (al.3-55), pl. 11-18 (al. Pl. 8-15).

Deflandre, G. \& I.C. Cookson. 1955. Fósil microplankton from Australian Late Mesozoic and Tertiary sediments. Australian Journal of Marine and Freshwater Research, v. 6, no 2: 242-313, pl. 1-9.

Digregorio, J.H. 1972. Neuquén. En: Leanza, A.F. (Ed.): Geología Regional Argentina, Academia Nacional de Ciencias de la República Argentina, Córdoba, pp. 539-506.

Duane, A.M. 1996. Palynology of the Byers Group (Late Jurassic-Early Cretaceous) of Livingston and Snow islands, Antarctic Peninsula: its biostratigraphical and palaeoenvironmental significance. Review of Palaeobotany and Palynology 91: 241-281.

Duane, A.M. 1997. Taxonomic invejstigations of palynomorphs from the Byers Group (Upper JurassicLower Cretaceous), Livingston and Snow Islands, Antarctic Peninsula. Palynology 21: 123-144.

Duxbury, S. 1977. A Palynostratigraphy of the Berriasian to Barremian of the Speeton Clay of Speeton, England. Palaeontographica, Abteilung B 160: 17-67.

Duxbury, S. 1980. Barremian phytoplancton from Spee- ton, east Yorkshire. Palaeontographica, Abteilung B 173: 107-146.

Edgell, H.S. 1964. The correlative value of microplancton in the Cretaceous of the Perth Basin, WA. Ann. Report of the Geological Survey of Western Australia 1963: 50-55.

Ehrenberg, C.G. 1838. Über das Massenverhältnis der jetzt lebenden Kieselinfusorienund über ein neues Infusorienkonglomerat als Polierschiefer von Jastraba in Ungarn. Abhandlungen Akad. Wissensch. Berlin, vol. 1: 109-135.

Ehrenberg, C.G. 1843. Über einige Jura-Infusorien Arten des Corallrags bei Krakau. Monatsberichte Akad. Wissensch. Berlin, pp. 61-63.

Eisenack, A. 1958. Mikroplankton aus dem norddeutschen Apt, nebst einigen Bemerkungen über fossile Dinoflagellaten. Neues Jahrbuch für Geologie und Paläontologie, Abhandlungen, v. 106, no 3, p. 383422, pl. 21-27.

Erkmen, U. \& W.A.S. Sarjeant. 1980. Dinoflagellate cysts, acritarchs and tasmanitids from the uppermost Callovian of England and Scotland: with a reconsideration of the "Xanthidium pilosum" problem. Geobios, Lyon, no 7: 45-99, pl. 1-8.

Evans, P.R. 1966. Mesozoic stratigraphic palynology in Australia. Australasian Oil Gas Journal 12: 58-63.

Evitt, W.R. 1963. A discussion and proposals concerning fossil dinoflagellates, hystrichospheres and acritarchs, I. National Academy of Sciences, Washington, Proceedings, vol. 49, p. 158-164.

Evitt, W.R., R.F.A Clarke \& J.-P. Verdier. 1967. Dinoflagellate studies III. Dinogymnium acuminatum n. gen., n.sp.(Maastrichtian) and other fossils formerly referable to Gymnodinium Stein. Stanford University Publications, Geological Sciences, v.10, $n^{\circ} 4: 1-27$, pl. 1-3.

Fensome, R.A., F.J.R. Taylor, G. Norris, W.A.S. Sarjeant, D.I. Wharton \& G.L. Williams. 1993. A classification of living and fossil dinoflagellates. Micropaleontology, Special Publication 7: 1-351.

Fensome, R.A. \& G.L. Williams. 2004. The Lentin and Williams Index of fossil dinoflagellates. 2004 Edition. American Association of Stratigraphic Palynologists Foundation, Contribution Series 42: 1909.

Gocht, H. 1957. Mikroplankton aus dem nordwestdeutschen Neokom (Teil I). Paläontologische Zeitschrift 31: 163-185.

Groeber, P. 1946. Observaciones geológicas a lo largo del meridiano 70․ Hoja Chos Malal. Revista de la Asociación Geológica Argentina 1: 177-208.

Harris, W.K. 1976. 15. Palynology of Cores from Deep Sea Drilling Sites 327, 328, and 330, South Atlantic Ocean. En: Barker, P.F. \& Dalziel, I. W. D. (Eds.): Initial Reports of the Deep Sea Drilling Project, Volume 36: 761-815, United States Government Printing Office, Washington.

Haskell, T.R. \& G.J. Wilson. 1975. Palynology of Sites 280-284, DSDP Leg 29, off Southeastern Australia and western New Zealand. En: Kennett, J.P. \& Houtz, R. E. (Eds.): Initial Reports of the Deep Sea Drilling Project, Volume. 29, United States Government Printing Office, Washington, pp. 723-741. 
Helby, R. 1987. Muderongia and related dinoflagellates of the latest Jurassic to Early Cretaceous of Australasia. Memoir of the Association of Australasian Palaeontologists 4: 297-336.

Helby, R., R. Morgan \& A.D. Partridge. 1987. A palynological zonation of the Australian Mesozoic. Memoir of the Association of Australasian Palaeontologists 4: 1-94.

Helenes, J. \& J. Lucas-Clark. 1996. Morphological variations in Gonyaulacysta. Palynology 21: 173-196.

Jain, K.P. 1975. Additional dinoflagellates and acritarchs from the Grey Shale Member of the Dalmiapuram Formation, south India. The Palaeobotanist 24: 170-194.

Jansonius, J. 1986. Re-examination of Mesozoic Canadian dinoflagellate cysts published by S.A.J. Pocock (1962, 1972) Palynology , v. 10, p. 201-223, pl. 1-6.

Lazo, D.G. 2006. Análisis tafonómico e inferencia del grado de mezcla temporal y espacial de la macrofauna del Miembro Pilmatué de la Formación Agrio, Cretácico Inferior de cuenca Neuquina, Argentina. Ameghiniana 43 (2): 311-326.

Lazo, D.G. 2007. Análisis de biofacies y cambios relativos del nivel del mar en el Miembro Pilmatué de la Formación Agrio, Cretácico Inferior de cuenca Neuquina, Argentina. Ameghiniana 44 (1): 73-89.

Lazo, D.G., G.A. Concheyro, E.G. Ottone, M.V. Guler \& B. Aguirre-Urreta. 2009. Bioestratigrafía integrada de la Formación Agrio en su localidad tipo , Cretácico Temprano de la Cuenca Neuquina. Revista de la Asociación Geológica Argentina 65 (2): 322-341.

Leanza, H.A. 1981. The Jurassic-Cretaceous boundary beds in West Central Argentina and their ammonite zones. Neues Jahrbuch für Geologie und Paläontologie, Abhandlungen 161: 62-92.

Leanza, H.A. 1999. Field Guide: The Jurassic and Cretaceous terrestrial beds from southern Neuquén Basin, Argentina. VII International Symposium on Mesozoic Terrestrial Ecosystems. Museo Argentino de Ciencias Naturales "B. Rivadavia". 23 pp., 9 Figs., 1 geologic map at scale 1: 250.000 .

Leanza, H.A. 2009. Las principales discordancias del Mesozoico de la Cuenca Neuquina según observaciones de superficie. Rev. Mus. Argentino Cienc. Nat., n.s. 11(2):145-184, Buenos Aires.

Leanza, A.F. \& H.A. Leanza. 1979. Descripción Geológica de la Hoja 37c, Catán Lil, provincia del Neuquén. Servicio Geológico Nacional Argentino, Boletín 169: $1-65$.

Leanza, H.A. \& C.A. Hugo. 1997. Hoja Geológica 3969III. Picún Leufú. Provincias del Neuquén y Río Negro. Servicio Geológico Minero Argentino, Boletín 218: $1-135$.

Leanza, H.A., U. Rosenfeld, W. Volkheimer \& A. Zeiss. 2000. Facies Evolution of the Mesozoic Neuquén Basin (Argentina) in Space and Time. Zeitschrift für Angewandte Geologie, Sonderheft 1: 95-102.

Legarreta, L. \& C.A. Gulisano. 1989. Análisis estratigráfico secuencial de la Cuenca Neuquina (Triásico Superior-Terciario Inferior). En: Chebli, G.A. \& L.A. Spalletti (Eds.): Cuencas Sedimentarias Argentinas, Universidad Nacional de Tucumán, Serie Correlación Geológica 6, Tucumán, pp. 221-243.

Lentin, J.K. \& , G.L. Williams. 1985. Fossil dinofla- gellates: index to genera and species, 185 edition. Canadian Technical Report of Hydrography and Ocean Sciences, no 60, 451 pp.

Lindemann, E. 1928. Abteilung Peridineae (Dinoflagellatae). In: Engler, A. und Prantl, K. (Edit.). Die natürlichen Pflanzenfamilien nebst ihren Gattungen und wichtigeren Arten insbesondere den Nutzpflanzen. Zweite stark vermehrte und verbesserte Auflage herausgegeben von A. Engler. 2. Band. Leipzig. Wilhelm Engelmann, pp. 3-104.

Loeblich, A.R. Jr. \& A.R. III. Loeblich. 1966. Index to the genera, subgenera and sections of the Pyrrhophyta. Studies in Tropical Oceanography, no 3 , $\mathrm{x}+94 \mathrm{pp}$.

Masure, E. 1988. Berriasian to Aptian dinoflagellate cysts from the Galicia Margin, offshore Spain, Sites 638 and 639, ODP Leg 103. Ocean Drilling Program, Scientific Results, Proceedings 103: 433444.

Monteil, E. 1991a. Revision of the dinoflagellate cyst genus Cometodinium Deflandre and Courteville, 1939, emend.: Enantiomorphy in a fossil dinoflagellate cyst population. Bulletin des Centres de Recherche Exploration-Production Elf Aquitaine 15: 439-459.

Monteil, E. 1991b. Morphology and systematics of the ceratioid group: a new morphographic approach. Revision and emendation of the genus Muderongia Cookson and Eisenack 1958. Bulletin des Centres de Recherche Exploration-Production Elf-Aquitaine 15: 461-505.

Morgan, R. 1980. Palynostratigraphy of the Australian Early and Middle Cretaceous. Geological Survey of New South Wales, Palaeontology Memoir 18: 1-153.

Neale, J.W. \& W.A.S. Sarjeant. 1962. Microplankton from the Speeton Clay of Yorkshire. Geological Magazine, v. 99: 439-458, pl. 19-20.

Norwick, M.S. \& D. Burger.1976. Mid-Cretaceous microplancton from the Bathurst Island; in Palynology of the Cenomanian of Bathurst Island, Northern Territory, Australia. Australian Bureau of Mineral Resources, Geology and Geophysics, Bulletin 151: 21-113.

Ottone, E.G. 2009. La flora cretácica de Cuenca Neuquina, su significado paleoambiental y paleoclimático. Revista de la Asociación Geológica Argentina 65 (2): 373-386.

Ottone, E.G. \& M.B. Aguirre-Urreta. 2000. Palinomorfos cretácicos de la Formación Springhill en Estancia El Salitral, Patagonia austral, Argentina. Ameghiniana 37: 379-382.

Pascher, A. 1914. Über Flagellaten und Algen. Deutsche Botanische Ges. Ber. 32: 136-160.

Peralta, P. 1996. Nuevos registros de dinoflagelados marinos en la FormaciónAgrio (Cretácico Inferior), Cerro Negro de Covunco, Cuenca Neuquina, Argentina. Revista Española de Micropaleontología 28:45-55.

Peralta, P. 1997. Dinoflagelados de la Formación Agrio (Cretácico Inferior) del Cerro Negro y Cerro Mesa de Covunco, Cuenca Neuquina. Tesis Doctoral, Facultad de Ciencias Exactas, Físicas y Naturales, Universidad Nacional de Córdoba, 213 pp. Unpublished. 
Peralta, P. 2000. Paleomicroplancton de la localidad del Cerro Mesa de Covunco (Hauteriviense temprano), Cuenca Neuquina, Argentina. Descripciones Sistemáticas. Revista Española de Micropaleontología 32: 123-130.

Peralta, P. \& W. Volkheimer. 1997. Paleoenvironmental aspects of the Lower Cretaceous Agrio Formation, inferred by dinocyst assemblages, Neuquén Basin, Argentina. Neues Jahrbuch für Geologie und Paläontologie, Abhandlungen 204: 19-33.

Peralta, P. \& W. Volkheimer. 2000. Early Cretaceous sea level variations and changes in dinocyst assemblages and organic matter components in the Neuquén Basin, western Argentina. Neues Jahrbuch für Geologie und Paläontologie, Monatschrift 10: 613-631.

Pocock, S.A.J. 1962. Palynology of the Jurassic sediments of western Canada. Part 2. Marine species. Palaeontographica, Abhandlungen. B 137: 85-153.

Quattrocchio, M. \& W.A.S. Sarjeant. 1992. Dinoflagellate cysts and acritarchs from the Middle and Upper Jurassic of the Neuquén Basin, Argentina. Revista Española de Micropaleontología 24 (2):67118, pl. 1-8.

Quattrocchio, M. \& W. Volkheimer. 1985. Estudio palinológico del Berriasiano en la localidad Mallín Quemado, Provincia de Neuquén, Argentina. Ameghiniana 21 (2-4): 187-204.

Quattrocchio, M. \& W. Volkheimer. 1990. Jurassic and Lower Cretaceous dinocysts from Argentina: Their biostratigraphic significance. Review of Palaeobotany and Palynology 65: 319-330.

Quattrocchio, M.E., M.A. Martínez, A. Carpinelli Pavisich \& W. Volkheimer. 2006. Early Cretaceous Palynostratigraphy, palynofacies and palaeoenvironments of well sections in northeastern Tierra del Fuego, Argentina. Cretaceous Research 27: 584-602.

Sarjeant, W.A.S. 1966. Dinoflagellate cysts with Gonyaulax-type tabulation. In: Davey, R. J., Downie, C., Sarjeant, W.A.S. \& Williams, G. L., Studies on Mesozoic and Cainozoic dinoflagellate cysts; British Museum (Natural History) Geology, Bulletin, Supplement 3, p.107-156.

Sarjeant, W.A.S. 1968. Microplankton of the Upper Callovian and Lower Oxfordian of Normandy. Revue de micropaleontology, v. 10, no 4, p. 221-242, pl.1-3.

Sarjeant, W.A.S. 1980 a. A restudy of a $19^{\text {th }}$-Century dinoflagellate cyst holotype from the Polish Upper Jurassic. Acta Palaeontologica Polonica, v. 25:279285, pl. 37.

Sarjeant, W.A.S. 1980b. A restudy of some dinoflagellate cyst holotypes in the University of Kiel collections. I. The Jurassic holotypes of Walter Wetzel (1966a,b). Meyniana, v. 32, p.113-1228, pl. 1-3.

Sarjeant, W.A.S. 1985. The German Aptian dinoflagel- late cysts of Eisenack (1958): a restudy. Review of Palaeobotany and Palynology 45: 47-106.

Sarjeant, W.A.S. \& L.E. Stover. 1978. Cyclonephelium and Tenua: a problem in dinoflagellate cyst taxonomy. Grana, v. 17, p. 47-54.

Stover, L.E. \& W.R. Evitt. 1978. Analyses of Pre-Pleistocene Organic-walled Dinoflagellates. Stanford University Publications, Geological Sciences 15: 1-300.

Taylor, F.J.R. 1980. On dinoflagellate evolution: BioSystems, v. 13, p. 65-108.

Torricelli, S. 1997. Two new Early Cretaceous dinoflagellate cyst species from the Monte Soro Flysch (Sicily, Italy). Review of Palaeobotany and Palynology 96: 339-345.

Volkheimer, W. 1980. Microfloras del Jurásico Superior y Cretácico Inferior de América Latina. Actas II Congreso Argentino de Paleontología y Bioestratigrafía y I Congreso Latinoamericano de Paleontología. Buenos Aires 1978, vol. V (1980): 121-136.

Volkheimer, W. \& D. Pöthe de Baldis. 1976. Significado estratigráfico de microfloras paleozoicas y mesozoicas de la Argentina y países vecinos. $2^{\circ}$ Congreso Iberoamericano de Geología Económica 4: 403-424.

Volkheimer, W. \& M. Prámparo. 1984. Datos palinológicos del Cretácico Inferior en el borde austral de la Cuenca Neuquina, localidad Estancia Santa Elena, Argentina. Parte I: Especies terrestres. 3o Congreso Latinoamericano de Paleontología (Oaxtepec, México, 1984), Memoria: 165-174.

Volkheimer, W. \& W.A.S. Sarjeant. 1993. Systematophora rosenfeldii, a dinocyst from the Lower Cretaceous of the Neuquén Basin, Argentina. Neues Jahrbuch für Geologie und Paläontologie, Monatschrift 4: 246-256.

Volkheimer, W. \& E. Sepúlveda.1976. Biostratigraphische Bedeutung und mikrofloristische Assoziation von Cyclusphaera psilata n. sp., einer Leitform aus der Unterkreide des Neuquén-Beckens (Argentinien). Neues Jahrbuch für Geologie und Paläontologie, Monatschrift 2: 97-108.

Weaver, Ch. 1931. Paleontology of the Jurassic and Cretaceous of West Central Argentina. Memoirs of the University of Washington 1: 1-469.

White, H.H. 1842. On fossil Xanthidia. Microsc. J. vol. 11, pp. 35-40, pl. 4.

Wiseman, J.F. 1979. Neocomian eustatic changes - biostratigraphic evidence from the Carnarvon Basin. APEA Journal 19: 66-73.

Wiseman, J.F. 1980. Palynostratigraphy near the Jurassic-Cretaceous boundary in the Carnarvon Basin, Western Australia. $4^{\circ}$ International Palynological Conference (Lucknow, India, 1976-77), Proceedings 2: 330-349.

Recibido: 01-IX-2010 Aceptado: 28-XII-2010 


\section{APPENDIX}

\section{List of species}

In this section a full list of the dinoflagellate cyst taxa studied from the Agrio Formation at Estancia Santa Elena locality is given. The classification follows that of Fensome et al. (1993). For citations of papers referred to in the list that follows, see Fensome \& Williams (2004). Full citations of papers published since that work, or cited when taxonomic proposals are made, are presented in the "References". In cases of doubtful determination (? or cf.), a brief explanation is given after citation.

Achomosphaera sp. A of Norvick \& Burger, 1976 (fig. 4.D) Circulodinium distinctum (Deflandre \& Cookson, 1955) Jansonius, 1986 (figs. 3.A-B)

Cometodinium sp. cf. C. habibii Monteil 1991a (The cf. refers to the difficulty to observe the position of the archaeopyle) (figs. 8.J-L)

Cyclonephelium cf. vannophorum Davey, 1969 (Identification is based on only one specimen of fair preservation) (fig. 8.H)

Cymososphaeridium sp. 1 of Davey, 1982

Dapsilidinium chems (Below, 1982) Lentin \& Williams, 1985 (fig. 3.C)

Dapsilidinium cf. duma (Below, 1982) Lentin \& Williams, 1985. (Identification is based on only one specimen of fair preservation) (fig. 3.D)

Florentinia cf. interrupta Duxbury, 1980 (The cf. refers to the greater complexity of the processes, especially the antapical process, in our material) (figs. 3.F and 5.C)

Achomosphaera neptuni (Eisenack, 1958a) Davey \& Williams, 1966 (fig. 5.B)
Heterosphaeridium? galiciae, Masure, 1988 (Identification is based on only one specimen of fair preservation) (fig. 5.D)

Hystrichosphaeridium pulchrum Deflandre 1935 (fig. 5.A)

Muderongia siciliana Torricelli, 1997 (figures 4.A-C)

Muderongia sarjeantii Volkheimer, sp. nov. (figs. 4.E-H)

Occisucysta tentoria Duxbury, 1977 (figs. 5.F-G)

Oligosphaeridium quattrocchioae Volkheimer, sp. nov. (figs 5.H-M and 6.A-B, F-H)

?Pervosphaeridium sp. (Identification is based on only one specimen) (figs. 7.A-B)

Pilosidinium filiatum (Davies, 1983) Courtinat, 1989 (fig. 5.E)

Prolixosphaeridium cf. anasillum Erkmen \& Sarjeant, 1980 (Identification is based on only one specimen) (fig. 9.B)

Protoellipsodinium cf. seghire Below, 1981 (Identification is based on only one specimen of fair preservation) (figs. 8.A-B)

Protoellipsodinium sp. (figs. 7.C-D)

Pseudoceratium pelliferum Gocht 1957 (figs. 8.C-F)

Sentusidinium cuculliformis Davies, 1983 (fig. 4.I)

Spiniferites lenzii Below, 1982 (fig. 7.E)

Spiniferites cf. S. speetonensis Duxbury, 1980 (Identification is based on only one specimen) (fig. 7.F)

Stiphrosphaeridium dictyophorum (Cookson \& Eisenack) Davey 1982 (figs. 6.C-D)

Stiphrosphaeridium sp. (fig. 6.E)

Systematophora silybum Davey, 1979a (fig. 3.E)

Tanyosphaeridium boletus Davey, 1974 (fig. 8.G)

Tanyosphaeridium isocalamum (Deflandre \& Cookson, 1955) Davey \& Williams, 1969 (fig. 8.K-L)

Tenua cf. hystrix Eisenack emend. Sarjeant, 1985 (Identification is based on only one specimen of fair preservation) (fig. 9. A). 